University of Nebraska - Lincoln DigitalCommons@University of Nebraska - Lincoln

USGS Staff -- Published Research

US Geological Survey

7-17-2017

\title{
Moving from Generalisations to Specificity about Mangrove -Saltmarsh Dynamics
}

Kerrylee Rogers

School of Earth and Environmental Science, University of Wollongong, kerrylee@uow.edu.au

Ken W. Krauss

Wetland and Aquatic Research Centre, U.S. Geological Survey

Follow this and additional works at: http:// digitalcommons.unl.edu/usgsstaffpub

Part of the Geology Commons, Oceanography and Atmospheric Sciences and Meteorology Commons, Other Earth Sciences Commons, and the Other Environmental Sciences Commons

Rogers, Kerrylee and Krauss, Ken W., "Moving from Generalisations to Specificity about Mangrove -Saltmarsh Dynamics" (2017). USGS Staff-- Published Research. 1049.

http://digitalcommons.unl.edu/usgsstaffpub/1049

This Article is brought to you for free and open access by the US Geological Survey at DigitalCommons@University of Nebraska - Lincoln. It has been accepted for inclusion in USGS Staff -- Published Research by an authorized administrator of DigitalCommons@University of Nebraska - Lincoln. 


\title{
Moving from Generalisations to Specificity about Mangrove -Saltmarsh Dynamics
}

\author{
Kerrylee Rogers $^{1}$ (D) Ken W. Krauss ${ }^{2}$
}

Received: 17 July 2017 / Accepted: 25 July 2018

(C) Society of Wetland Scientists 2018

\begin{abstract}
Spatial and temporal variability in factors influencing mangrove establishment and survival affects the distribution of mangrove, particularly near their latitudinal limit, where mangrove expansion into saltmarsh is conspicuous. In this paper the spatial variability in mangrove distribution and variability in factors influencing mangrove establishment and survival during the Quaternary period are reviewed, focussing on research at latitudinal limits in Australia and mainland USA. Despite similarities in the response of mangrove to some drivers, the expression of these drivers is both spatially and temporally variable, demonstrating the need for analyses of mangrove-saltmarsh dynamics to move beyond generalisations and incorporate regional and local-scale specificity. We propose i) that precursory recognition that 'correlation does not mean causation' is inadequate and assumptions, caveats, and limitations should be clearly articulated in correlative studies; ii) experimental design in manipulative experiments must also articulate the spatial and temporal scale to which the analysis is relevant; and iii) analyses that draw from a range of methods will provide greater confidence. Integrated research programs that transect spatial and temporal scales and incorporate a range of techniques are essential to improve projections. Mangrove-saltmarsh distribution research should move beyond simple models that assume equilibrium between realised and fundamental niches.
\end{abstract}

Keywords Climate change $\cdot$ Sea-level rise $\cdot$ Frost or freeze $\cdot$ Spatial and temporal variability $\cdot$ Hierarchy theory

\section{Introduction}

Mangrove forests, trees and shrubs typically occupy the upper intertidal zone and are regularly inundated by tidal waters. Mangroves thrive where inundation typically occurs daily, often at tidal positions near mean sea level to mean high water. Mangroves reportedly occupy between $83,495-137,760 \mathrm{~km}^{2}$ along coastlines in 118 countries and territories (Giri et al. 2011b; Hamilton et al. 2016). Despite this large spatial distribution, it is evident that mangrove forests do not occupy all shorelines globally even where they can climatically, and while they exhibit a close association with sea level, other factors also control the distribution of mangrove on shorelines. Strong spatial patterning in global mangrove

Kerrylee Rogers

Kerrylee@uow.edu.au

1 School of Earth and Environmental Science, University of Wollongong, Wollongong, NSW 2522, Australia

2 Wetland and Aquatic Research Centre, U.S. Geological Survey, Lafayette, LA 70506, USA distribution occurs with areal extent greatest in the tropics (Giri et al. 2011b), notwithstanding significant human impacts on mangrove forests in this region (Duke et al. 2007; Richards and Friess 2016).

A corresponding pattern of species diversity also exists with species counts attenuating away from tropical shorelines towards sub-tropical and temperate shorelines (Duke et al. 1998a; Saenger 2002). This strong spatial patterning has long been associated with temperature and at least as early as 1956, it was proposed that mangrove develop best when i) average temperature of the coldest month exceeds $20^{\circ} \mathrm{C}$; ii) development occurs in a fine-grained alluvium substrate; and iii) shorelines are free from strong wave action (West 1956). As a general rule these prerequisites still hold true; however, increasing access to higher resolution temperature data and observations of mangrove health and distribution have demonstrated that mangrove distribution is more nuanced than this rule would present (Quisthoudt et al. 2012; Osland et al. 2013; Cavanaugh et al. 2014; Osland et al. 2016). Exceptions in the global pattern of mangrove distribution are evident on the basis of biotic tolerances to temperature (Stevens et al. 2006; Stuart et al. 2007; Krauss et al. 2008), and variation in physical 
processes such as oceanic currents, rainfall, geomorphic settings and geographic barriers (Ball and Sobrado 1998; Saenger 2002; Quisthoudt et al. 2013; Semeniuk 2013; Saintilan et al. 2014). Consequently, the latitudinal range of mangrove forests is large, extending between $32^{\circ} \mathrm{N}$ and $38^{\circ} \mathrm{S}$ (Quisthoudt et al. 2012; Saintilan et al. 2014).

Recent observations of changes in mangrove distribution have motivated debate about controls on mangrove distribution. In southeastern Australia mangrove expansion was initially documented to occur in response to factors relevant at the local-scale and based largely upon comparisons of current and past distribution from aerial photography dating to the 1940s. Through a compilation of 28 independent studies of mangrove expansion across the intertidal zone, Saintilan and Williams (1999) established that the pattern of mangrove expansion into saltmarsh was regional in scale. Proposed mechanisms facilitating mangrove expansion into saltmarsh include changes in rainfall, changing agricultural practices, altered tidal regimes (including eustatic sea-level rise), sedimentation and nutrient addition, and subsidence. A regional pattern of mangrove proliferation has also been established along the Gulf of Mexico following a long period absent of extreme freeze events (Sherrod and McMillan 1985; Osland et al. 2013; Cavanaugh et al. 2014). Evidence of mangrove expansion at latitudinal limits has been compiled, differentiating patterns of change in mangrove distribution across the tidal frame from changes occurring at the latitudinal extremes of mangrove distribution (Saintilan et al. 2014). By necessity, this data compilation was large in spatial extent and identified a pattern of mangrove expansion at poleward limits that applied to both the northern and southern hemispheres and five continents (Asia, Australia, North America, Africa and South America). As per the prior compilation, the authors cautiously presented hypotheses for poleward expansion explaining the changes in distribution, including temperature increases, barriers to propagule dispersal, and elevated atmospheric $\mathrm{CO}_{2}$ concentrations, which mirrors global patterns of woody shrub encroachment of grasslands (Saintilan and Rogers 2015).

Coincident with these observations is evidence that increasing atmospheric $\mathrm{CO}_{2}$ concentrations are elevating air and sea surface temperatures, altering rainfall patterns and increasing sea levels. Due in large part to the correlation between changing mangrove distribution and anthropogenic climate change, studies are focussing on establishing whether climate change is implicated in observed changes in mangrove distribution. As mangroves are closely associated with the position of the sea at local scales, it is not surprising that there has been considerable focus on the relationship between sealevel rise and mangrove distribution changes. More recently, mangrove distribution at the local scale has been associated with temperature and aridity (Osland et al. 2016; Ximenes et al. 2016). Ecophysiological studies have considered the role of elevated $\mathrm{CO}_{2}$, and the interactions between elevated $\mathrm{CO}_{2}$, nutrient additions, water-use efficiency, sea-level rise, salinity changes and mangrove distribution (Farnsworth et al. 1996; Ball et al. 1997; Ball and Munns 1992; McKee and Rooth 2008; Langley et al. 2009). Influenced by a need to plan for climate change and promote ecosystem adaptation, research is now being directed towards projecting mangrove distribution. This is typically achieved using modelling techniques, establishing ecosystem niches and applying a range of IPCC scenarios of temperature increases and sea-level rise (Traill et al. 2011; Oliver et al. 2012; Record et al. 2013; Cavanaugh et al. 2015).

Underlying all models is a degree of uncertainty regarding the influence of parameters. For models projecting mangrove distribution, uncertainty increases when processes controlling distribution are poorly understood, or inadequately parameterised (Cowell and Thom 1994). Understanding controls on mangrove distribution becomes even more important when projecting models beyond the spatial and temporal scale that they are based, as uncertainty is compounded by projection (De Vriend 1991; Terwindt and Battjes 1991). Using case studies of mangrove and saltmarsh dynamics near the latitudinal range limit of mangrove from southeastern Australia and the Gulf of Mexico, we specifically discuss the effect of spatial and temporal scaling on mangrove distributions in the context of hierarchy theory. This is achieved by recognising spatial variability, and synthesising literature focussed on mangrove distribution changes over three timescales (i.e. the geological and Holocene, contemporary and observational, and projection timescales). We demonstrate the need for cause and effect models, ecological niche models and subsequent projections to move beyond generalisations of mangrove distribution changes and integrate information across a range of spatial and temporal scales. By adequately addressing how local and regional scale factors mediate mangrove distribution changes, we endeavour to add clarity to the ongoing discussion regarding controls on mangrove distribution and projections of mangrove distribution into the twenty-first century.

\section{Spatial and Temporal Heirarchy of Controls on Mangrove Distribution}

Spatial and temporal scaling of processes and effects have been recognised relatively recently by ecologists (Wiens 1989), but is the foundation of other disciplines such as geography and earth science. For coastal sedimentary environments, such as those occupied by mangrove, Wright and Thom (1977) recognised the need to integrate 'process' geomorphology with 'historical' geomorphology, and proposed that this was best achieved with a conceptual model that reflected the observed variation in coastal geomorphology in time and space, a concept that has also been projected for future scenarios (Woodroffe and Murray-Wallace 2012). 
For intertidal wetlands, there is growing awareness that scaling should go beyond considering ecological and morphological processes and integrate other physical processes (Friess et al. 2012). For mangrove, a systematic review of the spatial hierarchy of controls on mangrove distribution was undertaken by Duke et al. (1998a) who distinguished processes relevant at global, regional, estuarine and intertidal scales. In this review, estuarine scales related to the longitudinal distribution of mangrove primarily as salinity gradients diminish along estuaries. Intertidal scales related to position within the tidal frame, which is controlled by the interacting effect of tidal inundation, groundwater additions and rainfall run-off on abiotic factors such as salinity and anoxia, and biotic factors such as propagule dispersal, plant productivity and competition. Spatial and temporal scaling effects were also documented by Twilley et al. (1999) with regard to mangrove structure and function. This study recognised different mangrove distribution patterns at four hierarchical scales. These scales correspond to factors influencing the: i) global distribution of mangrove (i.e. temperature); ii) geomorphological settings (as per Thom (1984) and Woodroffe (1992); i.e. river delta, tidal estuary, lagoon and carbonate reef); iii) ecological forest types (as per Lugo and Snedaker (1974); i.e. riverine, fringe, basin, dwarf); and iv) habitat units within forests at the smallest spatial scale. Processes influencing mangrove were also conceptualised along a temporal scale ranging from an hour to a thousand years. For the Brazilian coastline, Schaeffer-Novelli et al. (2000) proposed four spatial units: i) site functional unit of $<0.1$ ha (representing individuals or small cohorts of trees); ii) patch level functional unit of 0.1-100 ha (broadly divided into fringing and basin types); iii) mangrove settings of 10-100 km (distinguished on the basis of geomorphology and landform type); and iv) coastal domains representing coastal segments of 500-1000 km length defined on the basis of oceanographic characteristics (e.g. wave- or tide-dominated coastline).

Despite general recognition that a range of factors operating at different spatial and temporal scales influence mangrove distribution, there are few studies that have attempted to integrate multiple factors to model either observed changes in mangrove distribution, or project future changes in distribution. Wright and Thom (1977) propose that development of disciplines focussed initially at macro scales and later at process scales may have limited appropriate integration of knowledge between scales. Wiens (1989) hypothesises that ecologists are intuitively interested in processes operating on anthropocentric scales, and bound by experimental design traditions where perceptual range may be limited. While these reasons may hold true, knowledge gaps and limitations in the availability of data at appropriate scales may also be limiting factors (Friess et al. 2012).

Hierarchy theory provides a useful framework for exploring the spatial and temporal dynamics in processes influencing mangrove distribution and has been used to conceptualise mangrove restoration trajectories (Twilley et al. 1999). Accordingly, an ecosystem is hierarchical when it operates on more than one spatial and temporal scale, or when different process rates are found in the system (O'Neill 1986; Giampietro 1994). Each level of the hierarchy can be regarded as a whole composed of smaller parts and also part of a higher level. For example, an individual mangrove comprises roots, leaves, trunks, flowers, and so on, but also combines with other individuals to comprise a forest. The influence of a process on any level of the hierarchy must also consider the influence of that process on both higher and lower levels. Extrapolation of this concept means that a process influencing a lower mangrove component, for example flowering, will also influence the higher order component, for example forest regeneration. While the interaction of processes at different levels and across multiple scales adds complexity to ecosystem dynamics, it also acts as a system of filters (Giampietro 1994). For example, poor forest regeneration at the patch scale acts as an indicator of flowering and reproduction problems at the individual level and enables exclusion of other processes operating at larger scales, such as a freeze events.

Application of this theory to models of mangrove distribution requires consideration of two hierarchical scales, space and time, and the interaction of processes operating at higher and lower scales to which the model applies. Consideration of the influence of rainfall on mangrove distribution at annual timescales, for example, requires consideration of the influence of decadal and inter-decadal oscillations, seasonal cycles and inter-annual variability, on rainfall patterns. At this scale global climate change is not as relevant as detection of a global trend and would be confounded by significant variability and error that would be attributed to factors operating at lower temporal scales (e.g. decadal variability).

Figure 1 conceptualises the spatial and temporal scale at which i) climatic/meteorological; ii) hydrological; iii) geomorphological/geochemical; and iv) ecophysiological processes operate, and therefore the spatial and temporal scale that these processes influence mangrove distribution. For simplicity these processes have been separated, and are far from an exhaustive list of processes influencing mangrove expansion. Importantly, interactions between processes are pivotal to ecosystem dynamics, causing both negative and positive feedbacks that can lead to self-organisation and stability, or can trigger a cascade of responses leading to ecosystem collapse (Cowell and Thom 1994). Again, using the rainfall example, the effect of annual changes in rainfall can trigger hydrological changes to groundwater availability and sealevel variability at inter-annual timescales, which can influence soil anoxia and salinity, shrink-swell of sediments, rates of organic matter decomposition, nutrient uptake, plant productivity and ultimately influence the health of mangrove individuals. This example has been demonstrated to influence 

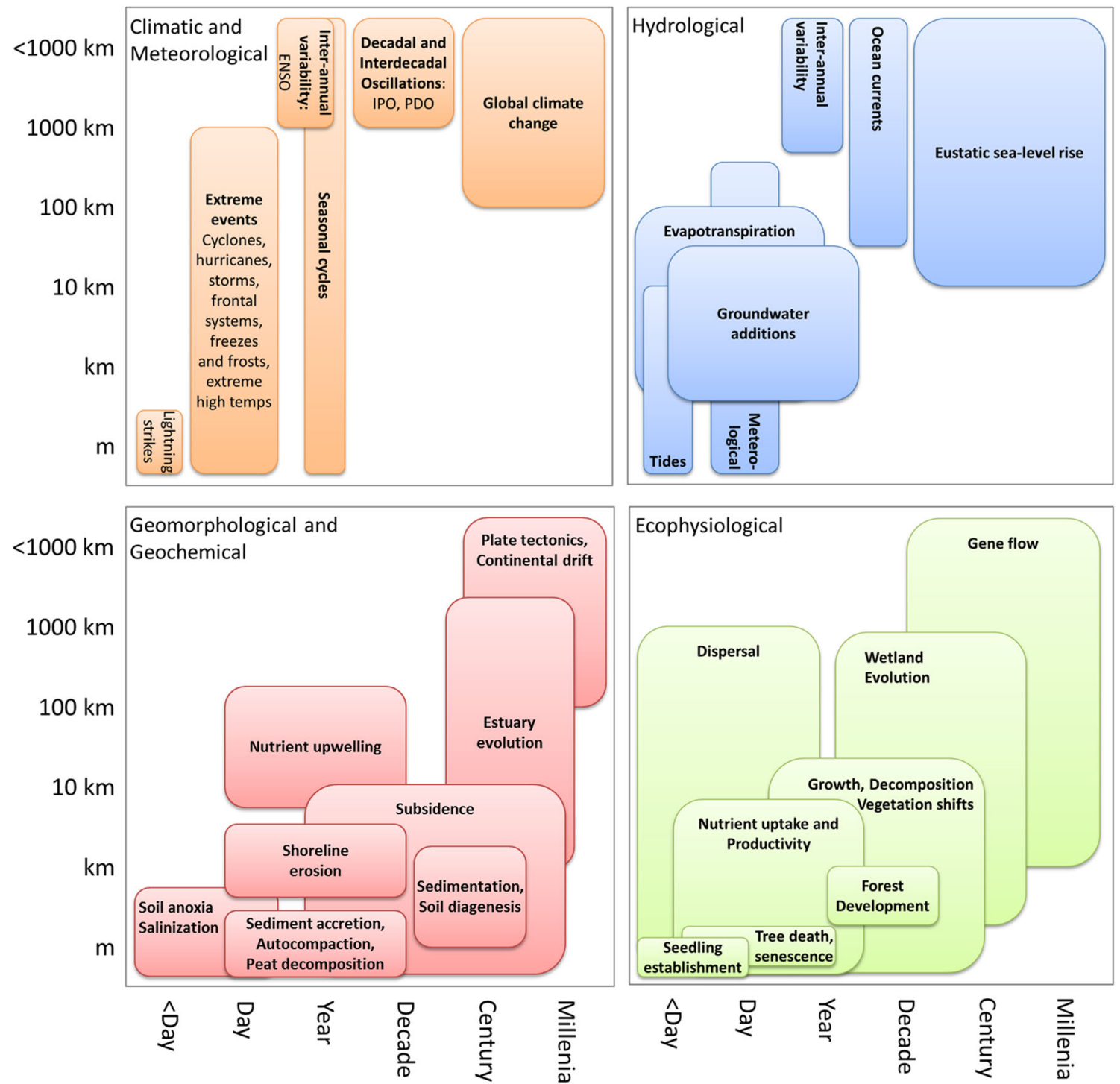

Fig. 1 Spatial and temporal scales over which various climatic and meteorological, hydrological, geomorphological/geochemical and ecophysiological processes operate

mangrove substrate elevation throughout southeastern Australia where periodic El Niño-Southern Oscillation (ENSO) cycles lead to reduced rainfall, depleted groundwater reserves, weakening sea-level rise and shrinkage of wetland surfaces (Rogers et al. 2005; Rogers et al. 2006; Rogers and Saintilan 2009). In this case disentangling the effect of reduced rainfall on ecosystem dynamics cannot be separated from coincident reductions in sea level over the same period (Rogers et al. 2014).

\section{Temporal Patterns in Mangrove Distribution}

Coastlines are highly dynamic and coastal scientists are increasingly aware of the changing environment in which mangrove resides. We know from fossilised mangrove pollen in the palaeontological record that mangroves have adjusted their geographic position in response to plate tectonics and global climatic change. For example, pollen from the mangrove palm (Nypa fruticans), which has evolved on intertidal shorelines for at least 75 million years (Schrank 1987; Gee 2001) and is one of the earliest angiosperms assigned a modern genus, has been documented from the Palaeocene $(\sim 66-$ $56 \mathrm{Ma})$ and Eocene ( $56-34 \mathrm{Ma})$ to have a wide distribution (Saenger 1998). Fossil spores have been found in Tasmania, Australia (Pole and Macphail 1996), Southeast England (Chandler 1978), Texas (Westgate and Gee 1990) and Southern France (Plaziat et al. 2001); where the climate currently contrasts significantly with the climate of extant $\mathrm{Nypa}$ populations of today. This period coincides with the lead into the Palaeocene-Eocene Thermal Maximum ( $\sim 56 \mathrm{Ma})$ and continental shift (Gee 2001), and biogeographic records from 
fossil pollen may indicate an influence of global warming and plate tectonics on mangrove distribution. 'Climate cooling' in the late Eocene, which coincides with the poleward distribution of mangrove pollen during the Eocene, and closure of the Tethys Sea have been hypothesised as the trigger for differentiation between mangrove in the Indo-West Pacific and Atlantic East Pacific (Plaziat and Cavagnetto 1996; Saenger 1998; Ellison et al. 1999). However, even at the largest of timescales, large-scale processes of climate change and plate tectonics do not adequately explain the presence or absence of mangrove from the fossil record. Loss of available habitat may have resulted in periods of mangrove extinction for some locations in the West and South Pacific (Woodroffe and Grindrod 1991; Ellison 2008). The extent of some mangrove species throughout the Miocene $(\sim 23-5.3 \mathrm{Ma})$ in the Pacific is stated to be greater than current distributions. Localised extinctions are reported to have occurred for Rhizophora on Enewetok Atoll in the Marshall Islands (Leopold 1969) and Sonneratia on Viti Levu in Fiji (Ladd 1965). Sea-level rise and its effect on accommodation space for mangrove is the hypothesised mechanism for these losses. Unfortunately, assertions related to palaeoclimates and continental drift are limited by incomplete knowledge of the prior position of continents and global temperatures, and it is probable that this hypothesis will remain for some time.

\section{Mangrove Distribution Changes over the Holocene}

The distribution of mangrove forests of today is not only an artefact of their evolution with respect to plate tectonics, propagule dispersal and a changing climate, but also associated with their response to sea-level changes and available accomodation space. This is most evident from documented changes in mangrove distribution during the Quaternary $(\sim$ past 2.5 Ma) (Woodroffe and Grindrod 1991), where evidence of mangrove distribution changes come from fossilised mangrove material in cores extracted from sediments deposited since the last marine transgression and during the Holocene ( past $11.7 \mathrm{ka}$ ) (Ellison 2008). Fossil material, including pollen and spores, and mangrove roots and peats, at depths below present mangrove distributions provide an indication of the influence of global eustatic sea-level rise on mangrove distribution and its interaction with regional isostasy. This evidence has been used for two related purposes. The first purpose is as an indicator of sea-level position over time. As mangrove peats and roots develop at depths below the soil surface, the imprecise nature of mangrove organic material as a sea-level indicator is typically recognised, and interpretation is undertaken in the context of evidence from other sea-level indicators such as notches, foraminifera, pollen, diatoms and coral dating (see, for example, McKee et al. 2007).

The second purpose draws from geological principles of uniformitarianism, whereby the present is a key to the past and by extrapolation, the past is a guide to the future (Woodroffe and Murray-Wallace 2012), with fossil evidence providing an indication of mangrove ecosystem response to sea-level rise. This application presumes that sea level and its interaction with sedimentary processes is the primary control on mangrove distribution, with the distribution of mangrove peats typically interpreted within the context of current geomorphology and enhanced with stratigraphic analyses from multiple cores positioned along a tidal/elevation gradient. This approach does not account for the variable response of species to sea-level rise or other physical processes (e.g. temperature). Figure 2 is the Holocene sea-level curve for southeastern Australia (Sloss et al. 2007) and Florida (Milliken et al. 2008), and demonstrates that there is generally reasonable correspondence between the position of mangrove peats, and other sea-level indicators in both regions. As a consequence of the correlation between multiple sea-level indicators over time, it is therefore reasonable to presume that the position of mangrove organic material within Quaternary sediments does provide a qualitative indication of ecosystem response to sea-level rise and relative sea level position, albeit limited by the imprecise nature of additions of organic material to substrates, and changes to organic material volume caused by peat oxidation, decomposition and $\mathrm{CO}_{2}$ efflux (Middleton and McKee 2001; Lovelock et al. 2011).

\section{Australia}

The generalised model of mangrove response to sea-level rise during the Holocene for tide-dominated estuaries in Australia (Woodroffe 1995), initially presented by Woodroffe et al. (1985), and substantiated by evidence of similar sequences of estuary infill for the Adelaide, Daly, Mary, Ord, King, and Hawkesbury Rivers (Thom et al. 1975; Chappell 1993), includes three phases (Woodroffe et al. 1993), though the exact timing of the phases varies between sites on the basis of rates of sediment supply. For the tide-dominated estuaries of northern Australia, these phases largely include the i) transgressive phase of sea-level rise (8000-6800 y BP) when mangrove encroached landward into terrestrial ecosystems; this was followed by the ii) big swamp phase (6800-5300 y BP) when sea level stabilised and mangrove was abundant, establishing throughout the current area of estuarine plains; and iii) sinuous/cuspate phase (since 5300 y BP) when mangrove retreated to meandering channels, point bars and shoals following significant vertical sedimentation during the prior phase.

The response of mangrove on wave-dominated southern coastlines of Australia differs from the northern tidedominated systems. Broad-scale mangrove colonisation would have been triggered by the development of lowenergy environments and substrate development. Precursory to these conditions was the formation of coastal barriers that 

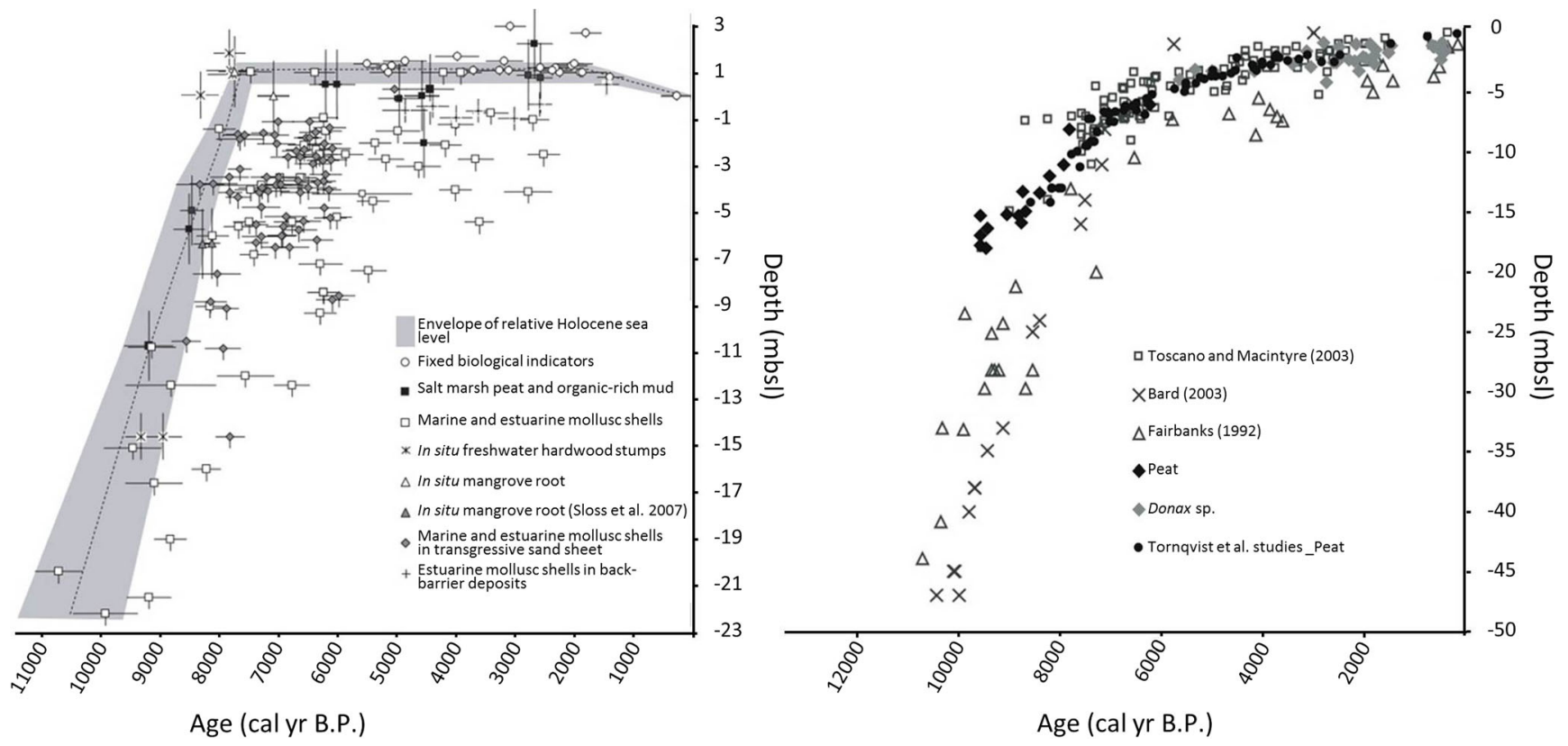

Fig. 2 Holocene sea-level curves from (a) southeastern Australia (as per Sloss et al. 2007) and (b) northern Gulf of Mexico (as per Milliken et al. 2008). Note the correspondence between mangrove peats and other sea level indicators in both regions

bounded estuary entrances of shallow embayments as sea levels stabilised approximately 7000 y BP (Roy et al. 2001). Evidence of mangrove colonisation is primarily based on mangrove root material as pollen of Avicennia marina does not preserve well in sediments, unlike the pollen of more tropical species (e.g. Rhizophora stylosa). For example, pollen analysis at Minnamurra River $\left(34.63^{\circ} \mathrm{S}, 150.86^{\circ} \mathrm{E}\right)$ indicated a transition from a tidal flat to saltmarsh ecosystem between 4300 and 2500 y BP (Jones 1990). Subaeial barrier development in deep embayments became the trigger for mangrove colonisation of low-energy substrates associated with floodtide and fluvial deltas as sea level stabilised within drowned river valleys. The position of fossil mangrove root material from the region corresponds to Holocene sea-level rise in the region (Saintilan and Hashimoto 1999; Hashimoto et al. 2006; Sloss et al. 2007), with a mangrove stump located near Bulli $\left(34.33^{\circ} \mathrm{S}, 150.91^{\circ} \mathrm{E}\right)$ with an elevation of $2.2 \mathrm{~m}$ above present mean sea level (PMSL) providing some evidence of a sea level high stand $2 \mathrm{~m}$ above PMSL (Jones et al. 1979).

\section{Mainland USA}

Parkinson (1989) presented a somewhat similar mangrove response model for carbonate settings in southwest Florida, which also has broad agreement throughout the Carribean (Evans et al. 1985; Hine et al. 1988; Stapor et al. 1988; Parkinson et al. 1994; McKee 2011). This region is ideal for extracting evidence of the Holocene response of mangrove to sea-level rise as peat building is primarily influenced by biotic processes, rather than abiotic processes such as sediment supply. In this model i) rates of sea-level rise were initially too rapid for broadscale development of coastal wetlands (15000$\sim 7000$ y BP); followed by a ii) deepening phase ( $>3500$ y BP) with rapid sea-level rise, shoreline retreat and development of transgressive facies sequences; and a iii) shallowing phase when the rate of sea-level rise was slower and shoreline stabilisation occurred. This was evident by relatively thick peat sequences on mainland shorelines, and when landscapes had a low gradient, mangrove transgressed inland (e.g., Krauss et al. 2011).

Along the northern coastline of the Gulf of Mexico where allochthonous sediment input is the primary source of material for substrate development there remains little evidence of mangrove colonisation over the Holocene (Sherrod and McMillan 1985), despite suitable accomodation space (Twilley et al. 2016). In this region, eradication of mangrove during the cooler conditions of the Pleistocene and early Holocene was proposed, with retreat of mangrove towards warmer shorelines closer to the equator (Sherrod and McMillan 1985). Evidence of mid to lateHolocene mangrove peats from Texas and Louisiana remain elusive from the abundant sediments of the region, despite periods of warm or warmer sea surface temperatures than current temperatures during the late-Holocene (Richey et al. 2007). The late-Holocene was marked by climatic variability, and colonisation from the genetically disparate populations of the east coastline (i.e. Florida) and the west coastline (i.e. Texas) of the Gulf of Mexico (McMillan 1986) may have been periodically halted; this climatic variability was proposed to facilitate natural selection for chill tolerant strains of Avicennia germinans (Sherrod and McMillan 1985). Substrate deterioration along the Mississippi River Deltaic Plain following avulsion, river abandonment and decreases in sediment input facilitated submergence and 
reworking of delta sediments during the Holocene (Twilley et al. 2016), potentially eroding any evidence of mangrove peats and organic material from delta lobes.

\section{Synthesis of Holocene Distribution Changes}

Despite similarities in the response of mangrove to sea-level rise, two primary differences emerge between Holocene mangrove development in Australia and mainland USA. First, the initiation of the transgressive phase in Australia occurred earlier ( $8000-6800$ y BP) than Florida ( $>3500$ y BP), which was followed by a longer period of shoreline stability in Australia when sea levels may have been up to $2 \mathrm{~m}$ higher than PMSL. Temporal variation in the timing of mangrove distribution changes can be partly explained by the variation in Holocene sea-level curves between the two regions in response to external glacio-isostatic processes of lithosphere deformation associated with ice sheet growth and melt that causes varying degrees of subsidence or uplift of the basement upon which wetland sediments accumulate and which influence global patterns of relative sea-level rise over the Holocene (Clark et al. 1978; Murray-Wallace and Woodroffe 2014). More specifically, Australia had a longer history of sealevel stability and evidence of a high stand during the Holocene, whilst in Florida the rate of sea-level rise declined over the mid to late-Holocene, but never exhibited an extended period of stability (Cronin 2012) (See Fig. 2).

Second, the influence of other climatic factors on mangrove distribution has varying importance between the two regions. In Australia, divergence of Avicennia marina eastern (var. eucalyptifolia), western (var. marina) and southern (var. australasica) varieties appears to have occurred during the Pleistocene ( $2.5 \mathrm{Ma}-11.7 \mathrm{ka})$ when lower sea levels isolated populations (Duke 1995; Duke et al. 1998b; Maguire et al. 2000). Southern populations have more ancient origins (Duke et al. 1998b), with evolution for cold tolerance potentially commencing in the mid-Cretaceous ( 100 Ma) (Duke 1995). There is little evidence that Holocene climatic variability influenced mangrove distribution in Australia. Current distributions are likely relicts from warmer climates and unlikely to reflect populations recovering from extreme events during the Holocene; Avicennia marina propagule buoyancy is relatively short (Clarke and Myerscough 1991), and markedly less than the buoyancy period for Rhizophora stylosa and Aegiceras corniculatum (Clarke et al. 2001), significantly limiting dispersal of propagules through constricted entrances of barrier estuaries along this coastline (Clarke 1993). Conversely, climatic variability in the northern Gulf of Mexico throughout the Late Holocene was significant, with sea surface temperatures reported to vary by approximately $3{ }^{\circ} \mathrm{C}$ over the past 1400 years (Richey et al. 2007). This variability may have prevented widespread mangrove establishment and the development of chill tolerance, despite available accommodation space. Propagule dispersal is evidently not a limitation for recovery with observations of propagules of Rhizophora mangle and Avicennia germinans in beach drift along the northern Gulf Coast (Sherrod and McMillan 1985). Given the propensity for mangrove dispersal throughout the Gulf of Mexico, early written accounts of mangroves in Mississippi and Louisiana in the 1700s and 1800s (Moldenke 1960; Chapman 1975) may correspond to a warming period following the Little Ice Age $(\sim 1300$ 1850) minima.

\section{Contemporary Mangrove Distribution Changes}

Mangrove dynamics during the Holocene provide the foundation upon which contemporary observations of ecotone dynamics occur. The most pervasive control on mangrove distribution since industrialisation has been the effect of humans directly through land cover conversion and indirectly through the alteration of coastal processes. A recent review documented the decline of mangrove and saltmarsh in Australia, primarily through the conversion of wetlands for flood mitigation purposes and achieved though drainage, ditching and dyking (Rogers et al. 2016). Along the Northern Gulf of Mexico within the influence of the Mississippi River delta, where wetland maintenance is dependent upon supply of sediment to offset deep subsidence, sediment autocompaction and sealevel rise, river management decisions, such as floodplain containment and reductions in sediment supply from upstream damming, have had the greatest influence on rates of wetland loss (Twilley et al. 2016). Excluding the direct influence of humans, observations in both Australia and mainland USA reveal a pattern of mangrove expansion, typically into adjoining saltmarsh (Saintilan et al. 2014).

\section{Australia}

Low-energy intertidal zones of coastal mainland Australia are occupied by both mangrove and saltmarsh, and mangrove species diversity typically decreases with increasing latitude, whilst the inverse pattern is evident for saltmarsh (Galloway 1982; Wells 1983; Rogers et al. 2016) (Fig. 3a). Mangrove is absent from the most southern state. Mangrove generally occupies lower elevations of the upper intertidal zone, while saltmarsh is restricted to higher elevations of the upper intertidal; rarely, and in particularly brackish conditions, Phragmites australis may seasonally grow as a narrow band in front of mangrove (Fig. 4a). At approximately the Tropic of Capricorn $\left(23^{\circ} 30^{\prime} \mathrm{S}\right)$ on both the eastern and western Australian coastlines, rainfall correlates with the relative proportion of mangrove and saltmarsh within the intertidal zone. Where rainfall is high, mangrove occupies a greater proportion of the intertidal and saltmarsh species may be restricted to a narrow zone that merges with adjoining hinterland habitats 
Fig. 3 Distribution of saltmarsh and mangrove, including number of mangrove species around the (a) Australian coastline and (b) northern Gulf of Mexico. Mangrove and saltmarsh are restricted to low energy environments and do not occur contiguously along the coastline. Based in information from (a) Duke (2006) and Rogers et al. (2016); and (b) Giri et al. (2011b), IUCN Red List (2017) and Mcowen et al. (2017)
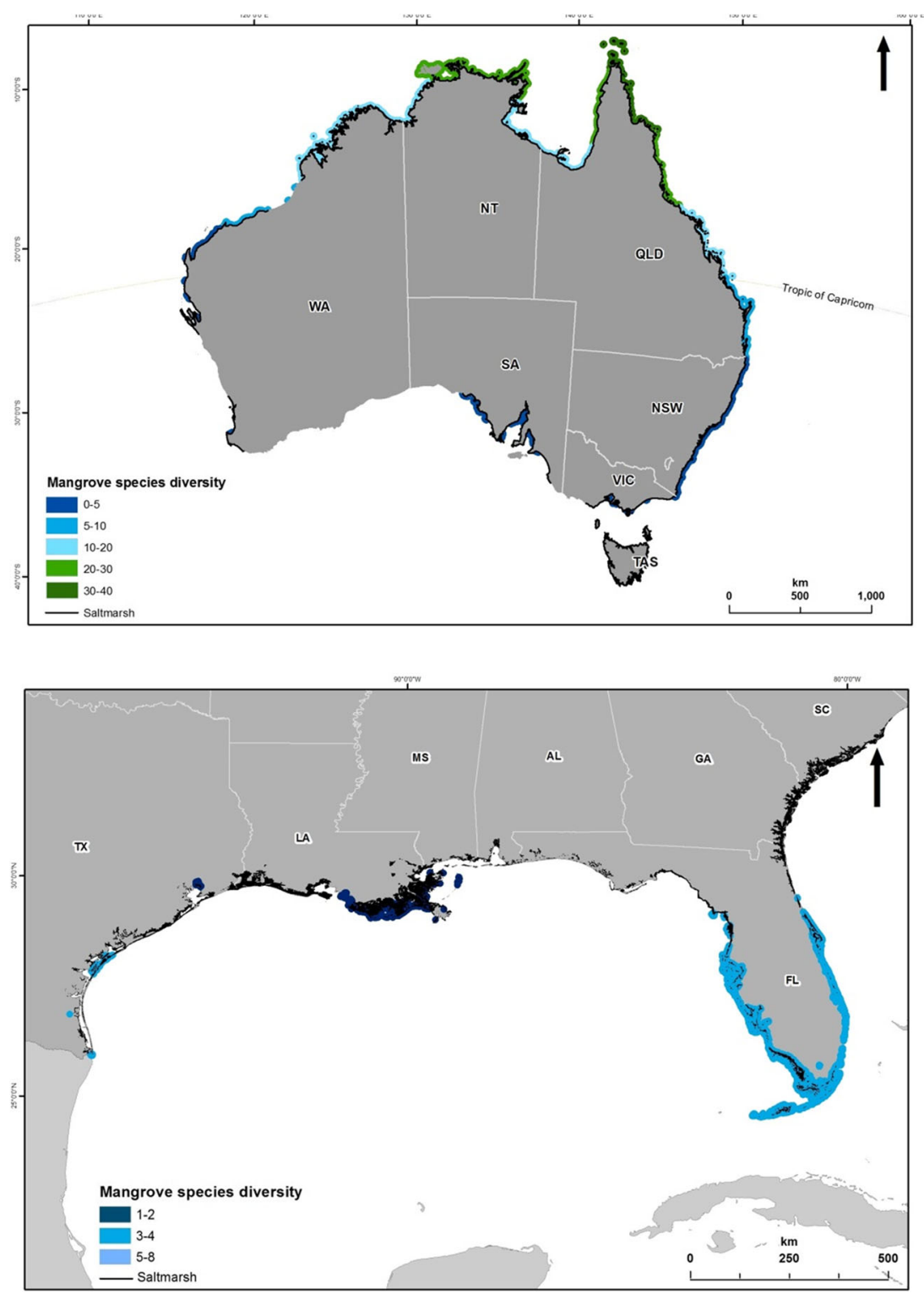

or freshwater wetlands (Bucher and Saenger 1994). In the intertidal zone of arid northwestern Australia, mangrove habitats give way to expansive salt flats dominated by cyanobacterial mats (Lovelock et al. 2010).

The southern coastlines of Australia are particularly suited for determining controls on mangrove distribution both within and between estuaries; here mangrove, particularly Avicennia marina, has occupied the intertidal zone for thousands of years (as discussed above) and theoretically has had sufficient time following $7000 \mathrm{y}$ of relative sea-level stability (See Fig. 2), to occupy their fundamental niche following major disruptions during the Quaternary period (as proposed by Woodroffe and Grindrod 1991). Geomorphic constraints on propagule dispersal and availability of suitable habitat are significant controls on the distribution of mangrove, particularly between estuaries where estuary entrance closure and associated small tidal prism reduce the available habitat for mangrove establishment and growth (Roy et al. 2001). Known regionally as intermittently closed or open lakes and lagoons, or ICOLLs, intermittent entrance closure of estuaries has been associated with restricted mangrove distribution in Australia, Brazil and South Africa (Haines et al. 2006; Adams et al. 2016; Saintilan et al. 2016). In addition to reduced habitat availability in the absence of notable tides, dispersal of propagules through intermittent estuary entrances may be limited, periodic flushing of salts which is essential for mangrove survival is diminished, and/or soils become anoxic when water levels are elevated following catchment rainfall. Lower air temperatures in southern Australia minimise the influence of evapotranspiration on soil physiochemical conditions; soil salinity and waterlogging 


\section{a)}

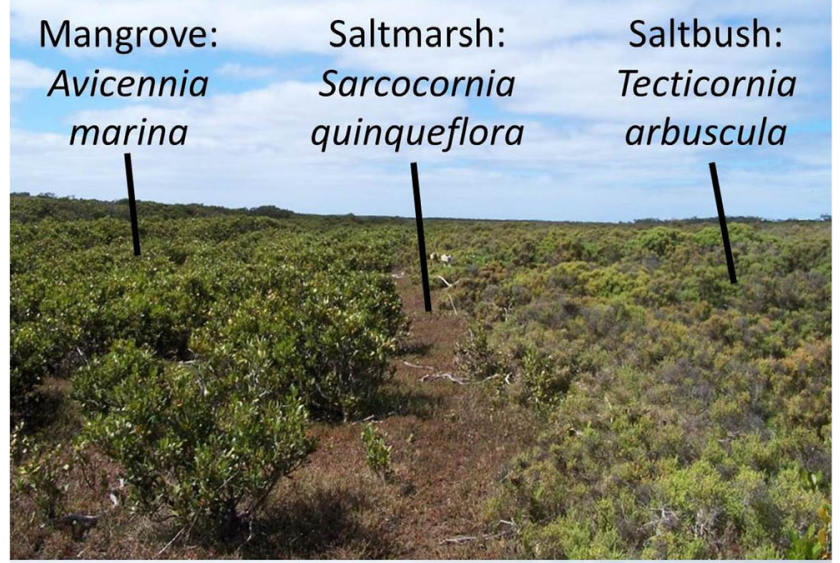

b)

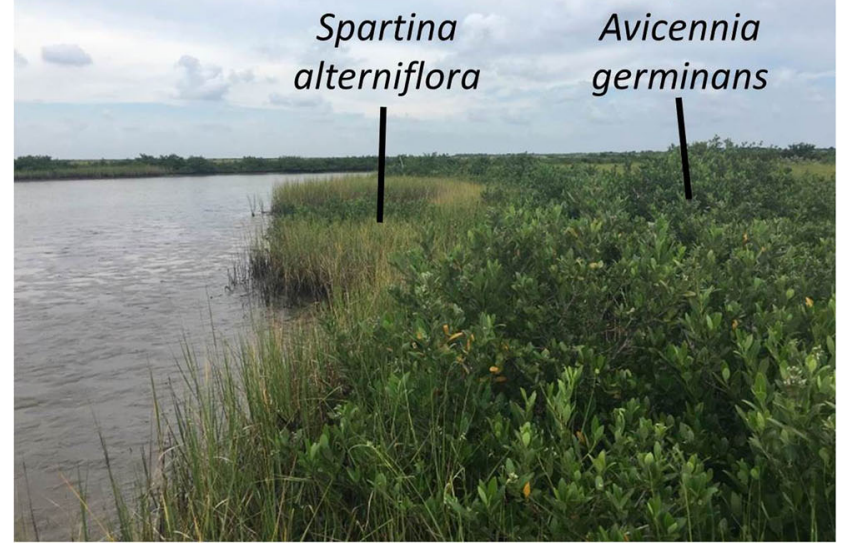

Fig. 4 Zonation of mangrove and saltmarsh at (a) Westernport Bay, southeastern Australia and (b) Port Fourchon, Louisiana. Lower elevations shown on left of each image, with the Avicennia marina typically positioned at lower elevations than saltmarsh in (a) southeastern Australia, and Spartina alterniflora typically positioned at lower elevations than Avicennia germinans in (b) Louisiana

controlled by position in the tidal frame appears to have a greater influence on propagule establishment and survival (Clarke and Myerscough 1993).

The southeastern coastline supports approximately 10 mangrove species (Duke 2006). Of those with the most southerly distribution, Rhizophora stylosa and Bruguiera gymnorrhiza (Wilson 2009) are reported to be increasing latitudinal range (Wilson and Saintilan 2012). Frosts or freezes are absent from the coastline near their southern limit and expansion correlates with a pattern of rising temperatures over the twentieth century (Nicholls and Collins 2006). On the basis of leaf phenology and longevity, Rhizophora stylosa has potentially not realised its thermally-defined niche with little difference in leaf phenology between southerly individuals and tropical counterparts (Wilson and Saintilan 2012). If true, and on the basis of suitable mangrove habitat within estuaries immediately south of the current extent, biotic factors may be an important determinant on range expansion between estuaries. Clarke et al. (2001) found a negative correlation between patterns of adult distribution of 14 mangrove species at macro-scales and propagule dispersal properties, proposing that factors influencing establishment may be a better predictor of adult distribution. Salinity did not limit shoot initiation or growth of Rhizophora stylosa (Clarke et al. 2001), but light may limit its establishment and growth, particularly at lower elevations where Rhizophora stylosa codominates with Avicennia marina (Smith III 1987), a species known for rapidly filling a regeneration niche (Clarke and Allaway 1993).

Aegiceras corniculatum does not occur south of Lake Merrimbula $\left(36.88^{\circ} \mathrm{S}, 149.90^{\circ} \mathrm{E}\right)$; its current range and intertidal distribution have remained relatively stable over the observational record, unlike Avicennia marina (Clarke 1995). Investment into reproduction is greater in Avicennia than Aegiceras, evident by larger propagules; fruit predation is higher in Aegiceras than Avicennia; and the establishment phase is longer for Aegiceras, thereby increasing opportunities for herbivory in early life stages (Clarke et al. 2001). Sinking of propagules at low salinities partly explains the zonation of Aegiceras, which is known as the River Mangrove as it favours lower salinities occurring in the upper estuary and across the intertidal zone when run-off or groundwater contributions are high (Clarke 1995). Zonation is also facilitated by growth and water use efficiencies at lower salinities (Clarke and Hannon 1970; Ball and Farquhar 1984; Ball 1988). The absence of Aegiceras corniculatum from more southerly estuaries is not surprising given the dominance of ICOLLs in southern NSW (Haines 2006) with intermittently open entrances, and differences in dispersal and establishment properties of Aegiceras and Avicennia (Smith III 1987; Clarke and Allaway 1993).

Avicennia marina var. australasica occupies the intertidal zone of temperate southeastern Australia and New Zealand; other varieties (var. marina and var. eucalyptifolia) are distributed along tropical coastlines (Duke 1991). This variety is particularly noted for intertidal expansion over the past century (Saintilan and Williams 1999) and cold tolerance (Stuart et al. 2007). The close proximity of the Great Dividing Range to the coast of southeastern Australia and the ensuing coastal escarpment has afforded some protection from cold fronts that move across the continent from the Southern Ocean. Consequently, frosts as they are regionally known (viz. freezes), are not severe and are relatively short in duration. The absence of Avicennia marina from Tasmania implies cold limitation; however, success of experimental plantings in Tasmania adds some credibility to the noted cold tolerance of this variety (noted in Woodroffe and Grindrod 1991). Consequently, there is significant evidence of a dispersal barrier, namely currents through Bass Strait, limiting establishment of mangrove on northern shorelines of Tasmania. Both mangrove and saltmarsh are virtually absent from the rocky 
coastline of the Great Australian Bight, with saltmarsh restricted to salt spray affected bluffs on cliffs and rocky shorelines (Saintilan and Rogers 2013). The tide-dominated estuaries near Adelaide, South Australia, do afford some protection from wave-energy from the Southern Ocean, and dense Avicennia marina occupy the intertidal zone between midtidal levels and spring high tide level, merging with saltmarsh dominated by succulents and saltbush (Gostin et al. 1984). These mangroves are expanding in the hypersaline conditions of these inverse estuaries (Burton 1982; Nunes and Lennon 1986). Similarly, mangrove and saltmarsh occupy low-energy shorelines of embayments along the southern coastline of Victoria. Corner Inlet, Victoria supports mangrove at the highest latitude of both the northern and southern hemispheres. While being shorter in stature than their tropical counterparts, their height is taller than the $0.5-0.8 \mathrm{~m}$ reported by Bridgewater and Cresswell (1999), with heights now ranging to $3 \mathrm{~m}$ (unpublished data.).

Multiple drivers were initially proposed for the observed intertidal expansion of mangrove in southeastern Australia in the twentieth century. These included precipitation in the latter part of the twentieth century, recovery of areas previously used for agricultural purposes, altered tidal regimes associated with engineering works within estuaries or sea-level rise, increased sedimentation and associated nutrients following catchment clearing, and subsidence of intertidal surfaces (Saintilan and Williams 1999). Nutrient addition has been precluded from facilitating mangrove establishment based on field experimentation, with carbohydrates in cotyledons purported to sustain mangrove in their first year (Saintilan 2003). Rates of mangrove expansion as related to relative sea-level rise, which included both sea-level rise at the nearest tide gauge and subsidence of the saltmarsh surface, have been established (Rogers et al. 2006). Expansion has also been correlated with increasing rainfall (Eslami-Andargoli et al. 2009). Regional rainfall and relative sea-level variation both correlate with broader climatic perturbations associated with ENSO, which confounds analyses aimed at distinguishing the influence of rainfall and sea-level rise on mangrove expansion (Rogers et al. 2014). This has been further validated by a nation-wide analysis of sea level trends and variability that demonstrated a strong influence of ENSO on sea level (White et al. 2014). Groundwater may also be a significant control on mangrove distribution with evidence that mangrove use groundwater as an alternative water source (Lovelock et al. 2017), mangrove distribution is influenced by fresh groundwater seepage (Semeniuk 1983), and mangrove and saltmarsh surface elevations decrease when groundwater is depleted (Rogers and Saintilan 2009).

Only one species of mangrove occupies the temperate intertidal zone of Western Australia. Avicennia marina var. marina (Duke 1991) is restricted to the intertidal zone of the Abrolhos Islands and Leschenault Inlet, and are regarded to be outliers from distributions during the Holocene (Woodroffe and Grindrod 1991). Dispersal of mangrove from these outlier populations may be limited by geomorphic constraints on the availability of suitable habitat along the wave dominated coastline of Western Australia. There are few estuaries between Shark Bay $\left(25.98^{\circ} \mathrm{S}, 113.78^{\circ} \mathrm{E}\right)$ and Hutt Lagoon $\left(28.16^{\circ} \mathrm{S}, 114.25^{\circ} \mathrm{E}\right)$; and these estuaries have relatively steep slopes, and little suitable habitat for mangrove establishment. Mangroves occur in all estuaries between Hutt Lagoon and Tobys Inlet $\left(33.64^{\circ} \mathrm{S}, 115.16^{\circ} \mathrm{E}\right)$ (Geosciences Australia 2011); but like southeastern Australia, estuaries of southwestern Australia undergo intermittent closure, and may restrict mangrove establishment in estuaries south of Bunbury $\left(33.33^{\circ} \mathrm{S}, 115.64^{\circ} \mathrm{E}\right)$.

In Northern Australia, saltwater intrusion and mangrove expansion have been associated with drier than average monsoonal conditions, low-intensity cyclonic events and aboveaverage ocean water levels (Knighton et al. 1991; Mulrennan and Woodroffe 1998; Winn et al. 2006), and demonstrate the overarching influence of climatic perturbations on local climate variables. Remote sensing of mangrove shorelines in the Gulf of Carpentaria indicated that Avicennia marina was expanding in a seaward direction where sedimentary conditions were favourable, and was accompanied by seaward expansion of Rhizophora stylosa into Avicennia marina forests (Asbridge et al. 2016). The cause of the resulting increase in mangrove width along the coast was correlated with increasing rainfall, flooding and sea-level rise in the region, with the combined effect being the development of mudflats and increasing inundation. Recent widespread dieback in Northern Australia may indicate that mangrove have an upper temperature threshold (Duke et al. 2017). The effect of high temperatures on photosynthetic carbon assimilation has been established for Australian mangroves (Clough et al. 1982; Andrews et al. 1984; Ball 1988); however, this dieback occurred at a time of high temperatures, lower sea levels and a rainfall deficit (Lucas et al., in press). Consequently, thermal stress has been suggested as one of a suite of possible causes (Duke et al. 2017). Interestingly, the recent dieback appears to have set-back the pattern of mangrove expansion that was evident in the decade prior (Lucas et al. 2018). The effect of thermal stress on mangrove is likely limited to tropical and arid coastlines, and is projected to have little effect on mangrove survival on temperate mangrove of southeastern Australia.

Elevated atmospheric $\mathrm{CO}_{2}$ concentrations may enhance plant growth and water use efficiency, with $\mathrm{C} 3$ plants including mangrove and many saltmarsh species, increasing growth rates in response to $\mathrm{CO}_{2}$ enrichment. In contrast, plants using the $\mathrm{C} 4$ photosynthetic pathway, which includes some saltmarsh species, are typically less responsive to $\mathrm{CO}_{2}$ (McKee et al. 2012). Ecophysiological studies focussed on Australian mangrove species have considered the effect of 
$\mathrm{CO}_{2}$, salinity and humidity on the perfromance of two mangrove species (Rhizophora stylosa and R. apiculata), demonstrating negative feedbacks between growth and carbon dioxide concentrations that are facilitated by improved water use efiiciency (Ball et al. 1997). These feedbacks were improved under enhanced humidity conditions, but not under conditions when salinity limited growth, indicating that elevated $\mathrm{CO}_{2}$ may not alter the salt tolerance of species, but could influence competition of species along salinity and aridity gradients. For species occurring near the latitudional limit in southeastern Australia (Avicennia marina and Aegiceras corniculatum), stomatal conductance and photosynthetic capacity decreased under conditions of ambient atmospheric carbon dioxide concentration, increasing salinity and decreasing humidity (Ball et al. 1997). As mangrove are C3 plants and may respond favourably to elevated $\mathrm{CO}_{2}$, it can be inferred that declines in photosynthetic capacity occurring due to salinity changes with sea-level rise or humidity changes with altered air temperatures may be ameliorated by enhanced growth under conditions of elevated $\mathrm{CO}_{2}$. The linkages between elevated atmospheric $\mathrm{CO}_{2}$, enhanced mangrove growth and mangrove expanion and saltwater intrusion in Australia have been inferred, but are yet to be clearly distinguished (Williamson et al. 2011; Saintilan and Rogers 2015).

\section{Mainland USA}

The intertidal zone of the northern Gulf of Mexico (i.e. mainland USA) primarily supports saltmarsh, on the east coast largely dominated by Spartina alterniflora as a lower marsh dominant, with other marsh species increasing in dominance along the western Gulf of Mexico (Texas) including Batis maritima, Sporobolus virginicus and Sesuvium portulacastrum (Jones et al. 2016). Only three true mangrove species occur along the shores of the US mainland: Avicennia germinans, Rhizophora mangle and Laguncularia racemosa, and their historic distribution has fluctuated along the shorelines of the southern US states (Fig. 3b). In the Eocene (approximately $45 \mathrm{Ma}$ ), mangrove pollen records indicate mangrove distribution as far north as the state of Tennessee, but certainly mangroves commonly occurred in the states of Alabama, Mississippi, Louisiana and Texas corresponding to warmer climates and higher sea levels (Sherrod and McMillan 1985). The pollen record became more obscure after the Eocene, but re-emerges in the mid-Holocene ( $\sim 3500$ y BP). As Caribbean mangroves at this time were limited only to equatorial regions this suggests eradication of mangroves from progressively colder temperatures before and into the Pleistocene (Sherrod and McMillan 1985). A postPleistocene recolonisation period initiated as the climate warmed. Accordingly, Avicennia was back in Texas by 1853 (Sherrod and McMillan 1985), whilst herbarium specimens of avicennia americana (syn. A. germinans) were collected in
1812 from Louisiana (McKee and Vervaeke 2018). Since this time, the recent historical northern limit for mangrove in eastern North America is believed to be near $30^{\circ} \mathrm{N}$ (Savage 1972), approximating a region near St Augustine, Florida $\left(29.90^{\circ} \mathrm{N}\right.$, $\left.81.31^{\circ} \mathrm{W}\right)$. The northern distribution of each mangrove species has been documented for the eastern coastline of Florida (Williams et al. 2014), with A. germinans having the most northerly distribution in 2013. The most northerly individual for each species was located between 26 and $67 \mathrm{~km}$ farther north than a prior assessment in 2007. Extreme freezes during the 1980s have been documented as a significant contributor to declines in mangroves throughout the northern Gulf of Mexico (McMillan 1986; Watson 1986; Montague and Wiegert 1990; Montague and Odum 1997), which are now recovering.

Controlled experiments indicate that freeze-induced embolism and its influence on hydraulic conductivity may alter distribution of mangrove at larger spatial scales, with interspecific differences mediated by xylem vessel architecture, and intraspecific differences mediated by genetic variability, trait evolution and/or phenotypic plasticity (Markley et al. 1982; Stuart et al. 2007; Madrid et al. 2014; Cook-Patton et al. 2015). Analyses of intraspecific variation along latitudinal gradients indicate that individuals near the range limit exhibit greater resilience to chilling than more equatorial populations (Cook-Patton et al. 2015). Vessel architecture also varies with soil salinity, and the combined influence of both temperature and salinity on vessel architecture, conductance capacity and carbon fixation potential may contribute to lower canopy heights where temperature and/or salinity approach tolerance thresholds (Madrid et al. 2014). Temperature thresholds on performance reportedly range between -2 and $-8^{\circ} \mathrm{C}$ for all three species (Osland et al. 2013; Cavanaugh et al. 2014; Osland et al. 2017), but there are important local-scale interactions embedded in this response related to saltmarsh species being replaced, and interactions between salinity and seedling age (Coldren and Proffitt 2017). A. germinans has been consistently found to be the most cold tolerant; however, comparative experiments with $A$. marina indicate significantly greater cold tolerance in the latter species, which does not occur in the USA (Stuart et al. 2007). There is reported variation in the tolerance of Rhizophora and Laguncularia that may relate to life stage of the plants (Markley et al. 1982; Cavanaugh et al. 2015; Cook-Patton et al. 2015). To this end, chilling tolerance has been found to vary with life stage. Greater cold tolerance of $A$. germinans at the dispersal stage, as opposed to stranded and seedling stages, may facilitate landward expansion of mangrove (Pickens and Hester 2011). Freeze damage is reportedly lowest for tall A. germinans and seedlings compared to short trees, whilst recovery following a freeze was highest for tall A. germinans (Osland et al. 2015).

Expansion of mangrove throughout mainland USA has generally been associated with the absence of extreme freezes 
in Florida (Stevens et al. 2006; Krauss et al. 2011; Cavanaugh et al. 2014; Rodriguez et al. 2016), Louisiana (Patterson and Mendelssohn 1991; Perry and Mendelssohn 2009; Osland et al. 2017) and Texas (Comeaux et al. 2012; Bianchi et al. 2013; Armitage et al. 2015). However, factors contributing to expansion have been difficult to differentiate due to the overarching influence of recovery following freeze events. Analyses of contemporary mangrove distribution dynamics in southern Florida, where studies have identified no discernible change in the pattern of freeze events throughout the region (Duever et al. 1994), provide the opportunity to control for extreme freeze events and explore the influence of other factors on mangrove distribution dynamics. Landward expansion of mangrove at various sites in southern Florida has been related to drainage of freshwater wetlands, diversion of run-off, changes in localised rainfall, sea-level rise, and factors facilitating propagule dispersal such as construction of new waterways and mosquito ditching (Teas et al. 1976; Ball 1980; Krauss et al. 2011; Smith III et al. 2013); declines in landward ecosystems have also been associated with sea-level rise (Ross et al. 1994; Doyle et al. 2010). Analysis of fringing mangrove extent at Tampa Bay $\left(27.76^{\circ} \mathrm{N}, 82.54^{\circ} \mathrm{W}\right)$ in the 1870 s from historical navigation maps indicate almost complete replacement of saltmarsh by mangrove. This expansion of mangrove attests to environmental changes operating at least over a century, with sea-level rise and freshwater withdrawal implicated (Raabe et al. 2012). The distribution of peats and marls underlying expanding mangrove forests at Biscayne Bay $\left(25.57^{\circ} \mathrm{N}\right.$, $80.23^{\circ} \mathrm{W}$ ) imply that recent landward expansion does not represent recovery to a prior extent, at least in recent history (Ball 1980). Unfortunately evidence of prior mangrove distribution in the greater Everglades region of south Florida may have been disturbed with peats largely oxidised or burned (McCally 1999).

Analyses of saltmarsh loss have also been associated with mangrove expansion following decades of relatively mild winters in Texas; however, conversion of saltmarsh to tidal flats or open water attests to the influence of sea-level rise on both mangrove establishment and saltmarsh conversion (Armitage et al. 2015). A more comprehensive approach incorporating multiple controls of mangrove extent near the northern limit of Florida proposed that $95 \%$ of variation in mangrove extent over time was explained by temperature, precipitation, sea level and time (Cavanaugh et al. 2015). While sea level only marginally improved model efficacy, the interacting effect of intertidal geomorphology and sealevel rise was not adequately incorporated within the model, which could be simply achieved by incorporating elevation within the model, or more accurately achieved with a hydrodynamic model. Just as most sea-level rise models have historically excluded climatic variables, most climatic models exclude sea-level rise and natural dispersal barriers, limiting inference of both model types.
As mangrove extent is periodically set-back by freezes, many studies have correlated increasing mangrove extent with potential drivers, particularly temperature. By extrapolation they have also correlated rates of poleward expansion and threshold temperature tolerances based on current distribution. For example, Williams et al. (2014) report hypothetical rates of poleward expansion, which presumes that absence of extreme freeze events are the primary determinant of poleward mangrove expansion. Cavanaugh et al. (2014) identify temperature related ecological thresholds, specifically reduction in frequency of days colder than $-4{ }^{\circ} \mathrm{C}$, which corresponds to historical estimates (Davis 1940). Similarly, Osland et al. (2013) propose a minimum temperature threshold of $-8.9^{\circ} \mathrm{C}$ for mangrove presence/absence, and $-7{ }^{\circ} \mathrm{C}$ for mangrove dominance. These temperature threshold estimates presume that mangrove currently occupy their fundamental niche; an assumption that has been questioned by Giri and Long (2014) who propose that mangrove expansion is not poleward in direction, but constitutes recovery following freezing temperatures in 1983 and 1989. Mangrove expansion along the eastern coastline is reportedly occurring within the historical northernmost limit, in this case documented using $\sim 35$ years of satellite imagery and occurring at a higher latitude in Louisiana in 1980 (Giri and Long 2016). Mapping of mangrove dynamics in this region attests to the interacting affect of multiple drivers upon mangrove distribution, with freezes causing dieback, milder temperatures associated with recovery, and subsidence and erosion variably associated with mangrove expansion and contraction dynamics between 1983 and 2010 in Louisiana (Giri et al. 2011a). To this list of possible causes could be added the early hypothesis of Penfound and Hathaway (1938), who documented dense mangrove stands near the coast of up to $7.6 \mathrm{~m}$ height, that have higher elevation and soil salinities than adjoining saltmarsh, and would readily invade lower communities except for annual marsh fires (but see Smith III et al. 2013). However, absence of fires in the subsequent years would preclude this hypothesis. Further evidence from the historical record and additional data sources, such as high-resolution elevation data (e.g. LiDAR), is required to confirm controls on mangrove establishment where distribution fluctuates over confounding micro-topographies and micro-climates.

At small spatial scales, mangrove establishment is strongly influenced by factors that influence the salinity of surface and soil water, and the degree of soil saturation. For example, in greenhouse growth studies seedlings of $A$. germinans exhibited favourable growth response under low to moderate levels of stress or disturbance associated with salinity regimes (optimal at 24-48 ppt), sediment burial (optimal at $0-10 \mathrm{~cm}$ ), and inundation depth (optimal at 15-30 cm) (Alleman and Hester 2011). In a field-based study measurements of basal increments indicated that growth correlated with hydroperiodmediated phosphorus subsidies for all species (Krauss et al. 
2006). The competitive growth response of stunted $A$. germinans is reflected in its higher water use efficiency and lower water demand at high salinities compared to Spartina alterniflora on at least one Louisiana site (Krauss et al. 2014). There is now increasing recognition of the role of biotic factors in mediating mangrove expansion, including propagule dispersal (Ball 1980), trapping of propagules by saltmarsh vegetation (Lewis and Dunstan 1975; Stevens et al. 2006; Peterson and Bell 2012), interspecific competition (Ball 1980; Patterson et al. 1993; McKee and Rooth 2008; Guo et al. 2013), and precocious reproduction (Dangremond and Feller 2016). More complex multifactorial effects between abiotic and biotic factors are also being recognised including $\mathrm{CO}_{2}$, nitrogen enrichment, facilitation, and differential warming influences in the mediation of competition between Spartina and A. germinans (Farnsworth et al. 1996; McKee and Rooth 2008).

Mangrove establishment in expanding zones has been conceptualised by Ball (1980) who proposed that seedlings will colonise any area that is available, providing propagules can be transported to the location and basic requirements are met (e.g. soil moisture prevents propagule desiccation). As reserves in cotyledons temporarily sustain establishment and development, species composition of seedlings in expanding areas does not reflect physiological tolerance to edaphic conditions or the role of competition; these factors become critical as individuals mature and competition for in situ resources becomes important.

\section{Synthesis of Contemporary Distribution Changes}

Studies in both regions that correlate mangrove expansion with other variables attest to a large scale pattern of mangrove expansion. While this expansion is currently synchronous in both regions, differences emerge that reflect species evolution over longer-timescales and the interacting effect of regionspecific processes. Time-series mapping from aerial or satellite imagery indicates that expansion is occurring in three directions: i) poleward or latitudinal expansion; ii) along estuaries (sometimes referred to as longitudinal expansion along eastern and western coastlines); and iii) across the intertidal zone.

Poleward Expansion Only limited evidence exists on the expansion of mangrove in the estuaries of southeastern Australia; Rhizophora stylosa and Bruguiera gymnhorriza may be expanding, Aegiceras corniculatum distribution is reportedly stable, while latitudinal expansion of Avicennia marina is limited by the geographic barrier of Bass Strait. Poleward expansion of mangrove has received considerably more attention in the mainland USA, particularly in the states of Florida, Texas and Louisiana. In this region, freezes are associated with climatic oscillations occurring in the North
Atlantic (North Atlantic Oscillation) and the Pacific (ENSO) (Downton and Miller 1993), operating over decadal timescales and causing periodic physical damage. Variation in these atmospheric circulation patterns and the ensuing ecological effects on mangrove distribution are poorly described using remote sensing techniques that have a relatively short temporal range (typically less than 25 years of data collection), as they do not adequately capture mangrove response to the full variation in the intensity and frequency of freeze events. In addition, studies that establish correlations based on patchy mangrove distributions may be more accurately explained by processes operating at smaller spatial scales, such as micro-climatic variability, propagule dispersal and nutrient availability. Expansion of mangrove is currently occurring within the range of mangrove distribution of the early 1980 s and likely represent recovery following dieback of mangrove, rather than northerly expansion beyond their historic range limits. When analysing temporal changes in species distribution it is important to distinguish between the range of environmental conditions in which a species establishes and survives, commonly identified as the fundamental niche, and the range of conditions in which a species currently occurs, defined as the realised niche. Based on the stochastic nature of freezes in North America, the current northern range of mangrove is likely to represent a realised niche, as distribution within the fundamental niche is periodically delimited by stochastic freeze events. Expansion of mangrove in mainland USA is now synchronous and occurring at all northern limits in Florida, Louisiana and Texas. This synchronicity in expansion relates to the large spatial extent of freeze damage to mangroves, and not to a single process operating consistently across mainland USA to facilitate mangrove establishment. Rather, recent mangrove expansion is likely related to processes operating over smaller spatial scales, such as hydroperiod, nutrient availability, competition, and propagule dispersal, enabling the realised niche to expand until mangrove occupy their fundamental niche. Relationships between the area of mangrove and time since freeze events are evident (Cavanaugh et al. 2014; Osland et al. 2017), but rarely recognise that processes contributing to mangrove establishment are also time dependent. Until mangrove has fully recovered and occupied their fundamental niche, identifying processes other than freezes controlling mangrove distribution over longer timescales (e.g. climate change effects on temperature and sea-level rise) will be masked by variability occurring over shorter timescales, and more specifically be influenced by episodic dieback and recovery following the freeze.

Along Estuaries Expansion of mangrove along estuaries, based on written, cartographic and pictorial materials from the Sydney region, indicates that mangrove was likely absent from the upper Parramatta River from the time of European occupation in 1788, expanding until the 1940s when aerial 
photography indicates mangrove extent began to be delimited by increasing urbanisation and industrialisation (McLoughlin 2000). Similar expansion of mangrove along the Hawkesbury River has been observed in response to increasing siltation up until the 1940s-60s when extensive mangrove areas were converted to other land uses (Recher et al. 1993). From this time mangrove proliferation has largely occurred across the intertidal zone (Saintilan and Williams 1999). The New South Wales (NSW) Government has mapped the upstream tidal and mangrove limit in estuaries along NSW in an effort to establish a benchmark against which subsequent changes can be monitored (DNR 2006). This pattern of mangrove expansion along the wave-dominated estuaries of southeastern Australia may be hydrologically similar to mangrove expansion associated with saltwater intrusion in the tide-dominated rivers of Northern Australia (Knighton et al. 1991; Mulrennan and Woodroffe 1998; Winn et al. 2006). Estuarine expansion of mangrove in the mainland USA is masked by mangrove recovery dynamics following prior freeze events, and the northsouth orientation of estuaries behind shore parallel barrier deposits and their connection to form the intra-coastal waterway along the Atlantic coastline of Florida.

Across the Intertidal Where the influence of frost or freezes is reduced, studies of mangrove expansion across the intertidal zone in both regions have been linked to a range of factors. Topographic control on expansion is evident in southeastern Australia (Rogers 2004) and southern Florida, attesting to an influence of hydroperiod on mangrove distribution. Postfreeze mangrove recovery exhibits a similar topographic pattern in some locations, reflecting a local scale niche defined by accommodation space or hydroperiod (see for example Armitage et al. 2015; Osland et al. 2017). Irrespective of the driver of change, the underlying affect on an individual mangrove is typically hypothesised to be either a decrease in soil salinity and/or anaerobic conditions associated with enhanced hydroperiod. Laboratory and field experiments support both hypotheses (Krauss et al. 2006; Alleman and Hester 2011). In Florida, factors operating at larger spatial scales that influence hydroperiod are typically implicated, such as sea-level rise; however, other site-specific factors operating at smaller spatial scales may also influence rates of mangrove expansion, including drainage of wetlands, forest fires and morphology of the intertidal zone. The large spatial scale at which expansion is occurring in southeastern Australia has also focussed attention upon climatic-related drivers such as rainfall and sea-level rise, with local factors proposed to mediate these drivers. Disentangling the coincident nature of drivers of mangrove distribution is difficult in both regions. Consequently studies that correlate mangrove distribution changes with possible drivers will fail to clearly identify a driver of current mangrove distribution changes. Field, laboratory or greenhouse based analyses at smaller spatial scales will provide essential information about the response of mangrove to various drivers. Analyses of this type are currently focussed on temperature thresholds in mainland USA (McMillan and Sherrod 1986; Pickens and Hester 2011), and tolerance to salinity and dispersal properties in southeastern Australia (Clarke and Myerscough 1991; Clarke 1993; Clarke and Allaway 1993).

\section{Projections}

Projections of mangrove distribution at a range of spatial scales have been prompted by management needs and a desire to improve ecosystem outcomes under a changing climate. Focussing primarily upon applying climate change projections at the landscape scale, these projections often apply scenarios of sea-level rise and temperature increase to project mangrove distribution or persistence. At the local or individual-scale, mangrove models focus on resource, regulator, and hydroperiod gradients under a range of disturbances (e.g. hurricanes, lightning strikes) to predict stand development and identify sensitive drivers (e.g. nutrient concentrations) for further experimental tests (see for example Berger et al. 2008; Twilley and Rivera-Monroy 2009).

\section{Australia}

As there is little evidence of thermal control on mangrove extent in southeastern Australia, projections in this region have focused on changes occurring across the intertidal zone associated with sea-level rise. The exact response of mangrove and saltmarsh to sea-level rise is dependent upon local topography, sediment sources, rates of sediment supply, and the rate of sea-level rise (Woodroffe 1990). As rates of sediment supply and subsequent vertical accretion are proportional to accommodation space or hydroperiod, empirical data indicate that sedimentation is always higher in mangrove compared to adjacent saltmarsh in southeastern Australia (Rogers et al. 2006), translating to greater gain in surface elevation and improved capacity to adjust to sea-level rise. Analyses of carbon addition as mangrove encroaches upon saltmarsh demonstrates the greater capacity of mangrove to add organic material to the substrates (Kelleway et al. 2016). The enhanced capacity of mangrove to accumulate organic and mineral sediments as the sea rises has been conceptualised to have negative consequences for saltmarsh (Vanderzee 1988; Saintilan and Rogers 2013; Kelleway et al. 2016). This may be further assisted by enhanced assimilation of atmospheric $\mathrm{CO}_{2}$ that improves growth and access to below-ground water resources (Saintilan and Rogers 2015).

Landscape-scale projections of mangrove-saltmarsh distribution based on empirical data that incorporate feedbacks between hydroperiod, mineral and organic matter additions, and sea-level rise have been developed using readily available models such as the 'sea level affecting marshes model' 
(Akumu et al. 2011; Traill et al. 2011; Runting et al. 2016; Mogensen and Rogers 2018) or empirically driven numerical models (Oliver et al. 2012; Rogers et al. 2012, 2013; Mogensen and Rogers 2018). Both modelling approaches extrapolate elevation and distance dependent relationships between surface elevation gain and sea-level rise. In all cases, these models emphasise the capacity of mangrove and saltmarsh to adjust to low-to-moderate rates of sea-level rise, particularly when landward barriers (e.g. infrastructure, steep topography, levees) to expansion across adjacent low-lying land are absent; this capacity appears to be exhausted under high rates of sea-level rise that approach or exceed $9 \mathrm{~mm} / \mathrm{y}$. With the exception of Rogers et al. (2013) which incorporated levee management in scenarios, model scenarios have focussed on sea-level rise alone. A three model comparison of Oliver et al. (2012), SLAMM and an adjusted version of Temmerman et al. (2003) demonstrated the influence that model selection and parameterisation has on projections (Mogensen and Rogers 2018). Few studies of the effect of sea-level rise have been undertaken at larger spatial scales; as modelling approaches that more accurately capture feedbacks between inundation and elevation adjustment are difficult to develop and apply at larger spatial scales, in all instances a relatively simple bath-fill approach was used to project an upper threshold of inundation (DCC 2009; Boon et al. 2011).

\section{Mainland USA}

Along much of the northern Gulf of Mexico where mangrove and saltmarsh occur sympatrically, mangrove is positioned at higher elevations along creek banks where hydroperiod is reduced, and Spartina alterniflora is positioned at lower elevations with elevated hydroperiods either where bank gradients provide suitable accommodation space or in the interior of the marsh (Patterson et al. 1997, Fig. 4b). Higher sulphide concentrations associated with lower elevations in Spartina were hypothesised to limit Avicennia propagule establishment (Patterson and Mendelssohn 1991), and subsequent seedling and propagule plantation experiments confirmed reduced seedling growth rates (Patterson et al. 1993) and greater propagule herbivory and decay at lower elevations (Patterson et al. 1997). Loss-on-ignition measurements from soil collected under adjacent marsh and mangrove sites in Texas indicate greater organic matter contributions and carbon components within the soil volume at the generally lower elevations occupied by Spartina than higher elevations occupied by mangrove (Comeaux et al. 2012). Despite slight elevation differences between mangrove and Spartina, vertical accretion and surface elevation change measures to date are trend-free overall (Perry and Mendelssohn 2009; McKee and Vervaeke 2018). As mangrove are still recovering or developing after prior freezes, soil carbon may not yet be saturated in freeze affected areas (Henry and Twilley 2013; Yando et al. 2016). However, this relationship is not consistent with mangrove carbon storage reportedly higher along a gradient of mangrove encroachment in Florida (Doughty et al. 2016). The pattern of carbon saturation beneath mangrove and saltmarsh is evidently site dependent and may be offset by rates of mineral sediment supply. This complexity and the overarching influence of freezes on mangrove distribution in mainland USA have resulted in projections focussing on the effects of increasing temperature on mangrove distribution.

Temperature thresholds that cause severe dieback of mangrove, derived using correlative techniques (Osland et al. 2013; Cavanaugh et al. 2014), have provided a means for extrapolation of mangrove distribution using various temperature scenarios. Osland et al. (2013) used a climate envelope approach to project mangrove forest presence and relative abundance within 352 coastal grid cells that covered a coastline of $172,024 \mathrm{~km}^{2}$ based on future climate scenarios at 2070-2100, projecting broad-scale mangrove expansion and saltmarsh decline. Guo et al. (2013), recognising that other factors will improve climate envelope approaches specifically examined biotic interactions between A. germinans and saltmarsh vegetation along the Texas coast, accounting for latitudinal gradient, elevational gradient and life history stages of mangrove. They demonstrated that the response of mangrove is variable depending upon each of these factors. In doing so, they demonstrate that biotic interactions are an important component of mangrove-saltmarsh dynamics. Ignoring the overarching influence of hydroperiod and its interaction with topography, Stevens et al. (2006) extrapolated rates of mangrove expansion after a freeze event to propose complete coverage of mangrove seedlings at Cedar Key within 25-30 years since their analysis. Similarly, a study calling for analysis to look beyond sea-level rise excluded inundation parameters and individual species tolerance to both temperature and aridity to project areas of high vulnerability to changes in mangrove-saltmarsh dynamics for the mainland USA and globally on the basis of aridity gradients, winter air temperature gradients, and a combination of both factors (Osland et al. 2016).

In southern Florida, where temperature control on mangrove survival does not dominate distribution dynamics, sealevel rise projections typically indicate landward expansion of mangrove. SLAMM has been used in this region to project changes in wetland vegetation classes indicating significant gains in tidal wetlands (mangrove and saltmarsh) at the expense of inland and coastal forest (Geselbracht et al. 2011; Sherwood and Greening 2014; Geselbracht et al. 2015). Comparisons of simple bath-fill approaches with SLAMM using elevation data of differing resolution demonstrate the usefulness of high resolution elevation models and improved vegetation distribution models (Zhu et al. 2015). At the regional scale, the sea level over proportional elevation 
(SLOPE) model, which assumes the area of mangrove and saltmarsh is determined by the landform slope and vertical tidal forcing, was applied to the northern Gulf of Mexico (Doyle et al. 2010). They demonstrate significant spatial variation in the proportion of tidal freshwater forest lost and saltwater mangrove-saltmarsh gain based on current rates of relative sea-level rise of $18-20 \mathrm{~cm}$ and $10 \mathrm{~cm}$ acceleration in eustatic sea-level rise over the next century. With the purpose of identifying barriers to landward migration, bath-full techniques were applied to LIDAR derived digital elevation models along the northern Gulf of Mexico (Enwright et al. 2016).

\section{Synthesis of Projections}

Due to the need to plan for sea-level rise and provide adaptation pathways for coastal wetlands, it is not surprising that projecting the response of mangrove and saltmarsh to sealevel rise has been the focus of research in both regions. All models are particularly sensitive to elevation and resolution/ accuracy of input digital elevation models. Application of SLAMM has been the predominant approach applied at the local scale, while bath-fill approaches were applied at the regional scale. Few studies have considered the influence of data input, model selection and parameterisation on model outcomes (Rogers et al. 2012; Mogensen and Rogers 2018; Zhu et al. 2015); this is an area requiring further research in both regions so that site-specific variables can be adequately incorporated. Given the influence of freeze events on mangrove survival in the northern Gulf of Mexico, it is also not surprising that this has received considerable attention in this region; unfortunately, these studies have yet to integrate the overarching influence of sea level and the expression of sea level on coastal topography to accurately project increases in mangrove extent. Integration of multiple controls on mangrove distribution within models has begun to receive some attention (Guo et al. 2013), and future model improvements are anticipated.

\section{Moving beyond Generalisations about Distribution Dynamics}

The distribution of organisms is determined by a range of factors including: the geographical starting point for dispersal; the inherited ecological niche; dispersal limitations imposed by abiotic conditions; opportunities for niche evolution; and the time over which dispersal and evolution can occur (Wiens and Donoghue 2004), with anthropogenic activities augmenting these processes. Distribution patterns derive from the interaction of these factors, and their influence on establishment and long-term survival of individuals at different spatial and temporal scales. Unfortunately, mangrove scientists are often lax in defining both the spatial and temporal scale of analysis; and this has been associated with contradictory interpretations due to correlations between variables that are not hierarchically comparable (Schaeffer-Novelli et al. 2000). In addition, few studies have analysed the broad range of factors controlling mangrove distribution (Friess et al. 2012). In an attempt to present a systematic treatise we have broadly identified a range of ecophysiological, geomorphological/geochemical, hydrological and meteorological/climatic processes influencing mangrove. While Fig. 1 presents these components as discrete units, it masks the complexity in these processes that intersect, combine, correlate, amplify and create feedbacks between and among each other. This complexity may be inherently limiting the capacity to move beyond generalisations regarding mangrove expansion.

Correlative techniques, commonly termed 'ecological niche modelling' or 'species distribution modelling' are becoming increasingly popular for ecologists and biogeographers (Peterson and Soberón 2012a, b), and dominate analyses of mangrove distribution. These techniques intend to establish relationships between mangrove distribution at various spatial and temporal scales with environmental variables, but are frequently used in ways whereby model outcomes do not correspond to what is known about species distribution in the real-world (Peterson and Soberón 2012a, b). Foundational to correlative studies is the assumption that the inherited ecological niche or fundamental niche is the primary control on distribution, that enough time has passed for the niche to be fully realised, and that this niche can be adequately defined using a few variables; that is, the niche they occupy is in dynamic equilibrium with correlative variables (Pearson and Dawson 2003). The paradox of these studies is that while they intend to describe mangrove distribution dynamics, they intrinsically ignore the spatial and temporal dynamics in mangrove ecosystems that allow mangrove to occupy a realised niche, as opposed to the fundamental niche. In addition, they fail to recognise the full range of factors that operate at similar spatial and temporal scales, and presume that factors operating at larger or smaller spatial scales are insignificant. In this regard, global scale analyses of mangrove expansion often ignore the local scale factors that can be so influential in rates of mangrove expansion and the proportional area of a wetland that mangrove occupies. While it is a well-known adage that 'correlation does not imply causation', emphasis of this concept is necessary, and further analysis is essential to confirm causation.

Climate change has necessitated the need for projections of mangrove and saltmarsh distribution under various climate change scenarios. However, the effect of assumptions from correlative studies are compounded when projecting mangrove distribution, particularly when the model is poorly parameterised and validated (Cowell and Thom 1994). Projecting species distribution changes under various climate 
change scenarios entails acceptance that species distribution is non-equilibrium in nature and should therefore be undertaken cautiously. Correlations based on analyses of mangrove distribution over short temporal scales or small spatial scales, are particularly prone to being poorly parameterised, as the probability of missing important processes influencing mangrove distribution over longer timescales and larger spatial scales will be high. The validity of these models has also been questioned as they primarily focus on climatic variables, ignoring the many other variables influencing species distribution (Pearson and Dawson 2003).

Manipulative experiments under field or laboratory conditions provide a means for validating observed spatial and temporal patterns established using correlative approaches, and afford additional evidence of causation. The outcomes of manipulative experiments can be fundamental to process based model development that can be used to project response to climate change variables (Dormann et al. 2012). However, they also incur their own challenges. First, they involve artificial manipulation of natural processes, which are inherently difficult to replicate. This is particularly pertinent under laboratory conditions where manipulation is largely limited to experiments on mangrove seedlings and juveniles, and unfeasible with adult mangrove. Second, experimental design in manipulative studies becomes increasingly difficult when manipulating processes operating over large spatial and temporal scales (Quinn and Keough 2002). Nevertheless, manipulative experiments provide important insights into the ecophysiological response of mangrove to environmental variables and should remain an important component of mangrove distribution research.

Our analysis of existing knowledge of the mangrovesaltmarsh distribution dynamics at a northern and southern hemisphere range limit of mangrove in Australia and mainland USA highlights the variation in processes influencing mangrove distribution within and between these regions. It also demonstrates the variation in processes that has occurred over geological, recent and contemporary timescales; establishing that there is little consistency in patterns of mangrove distribution between the regions. Planning for climate change requires some confidence in the ecological niche of mangrove and therefore necessitates acknowledgement of these differences. We therefore propose important considerations for biogeographical analyses that will assist with improving knowledge of mangrove distribution and enhance model confidence.

First, assumptions, caveats and limitations with correlative studies should be acknowledged and go beyond precursory acknowledgement that correlation does not mean causation. This requires recognition that both environmental controls on mangrove distribution, and mangrove distribution in itself, are spatially and temporally variable; sampling data are therefore incomplete, represent a 'snapshot' in space and time, and may be biased (Jarnevich et al. 2015). Establishment of relationships that are more robust requires that predictor variables capture the bounds of the variability and the periodicity of variability. Not incorporating this variability will result in established relationships between the realised niche of mangrove distribution and environmental variables, and will have little value for projections of future distribution. In addition, the observed variability means that it is unreasonable to expect one correlational model to reproduce mangrove distribution for all species, at all spatial scales, and across all temporal scales.

Second, the same recognition is also required for manipulative studies, whether they occur in the field or under laboratory conditions in greenhouses. In this regard, experimental design is particularly important, and experimental design should account for spatial and temporal variability in environmental variables. This requires ecologists to extend the perceptual range of feasible experimental designs, as proposed by Wiens (1989). This can become particularly difficult under field conditions due to spatial heterogeneity, but nevertheless requires careful experimental design (Dutilleul 1993). Importantly, results of physiologically-based experiments should be interpreted in the context of the full range of possible drivers of mangrove distribution, including those factors that are poorly or impossible to replicate in manipulative experiments (Pearson and Dawson 2003).

Third, analyses that draw from a range of methods will provide greater confidence in model outcomes. Integration of correlation techniques with manipulative experimentation is increasingly advocated in biogeographic literature (Pearson and Dawson 2003; Guisan and Thuiller 2005; Guisan et al. 2006). Correlative studies can be used to formulate hypotheses regarding controls on mangrove distribution that can be subsequently applied as test variables in manipulative field and laboratory experiments, thereby establishing the physiological response of mangrove to the environmental variables observed to influence mangrove distribution. Alternatively, findings from manipulative experiments can be verified by observing similar patterns in nature, or not if the physiological response was misinterpreted.

Frameworks have been advocated that integrate layers of information influencing species distribution, including bioclimatic variables, dispersal, disturbance and resource factors that limit species to a realised niche (see for example Pearson and Dawson 2003; Hijmans and Graham 2006; Franklin 2010). Distribution or niche modelling, sometimes termed ecological niche modelling (ENM), species distribution modelling (SDM) or community distribution modelling (CDM), provide the means of modelling species distributions from distribution records. The availability of MaxEnt (Elith et al. 2011) or BIOMOD (Thuiller et al. 2009) tool sets, particularly within GIS and statistical applications, have improved the popularity of these approaches (Peterson and Soberón 2012a). Currently, there are few applications of these 
approaches to modelling mangrove distribution (see for example Kramer-Schadt et al. 2013; Quisthoudt et al. 2013; Record et al. 2013), perhaps reflecting the need for model improvements. Distribution/niche modelling approaches are largely correlative in nature and aim to find associations between distribution data and abiotic predictors that are typically climatic, hydrological or geomorphological derivatives (Peterson and Soberón 2012a). There is considerable debate regarding the suitable application of distribution/niche modelling approaches, and many improvements have been proposed; users should refer to these suggestions prior to application (see for example Araújo and Guisan 2006; JiménezValverde et al. 2008; Peterson and Soberón 2012a, b). Whilst distribution/niche modelling may provide a first approximation of abiotic controls on mangrove distribution when applied appropriately (Record et al. 2013), model outputs will be significantly improved by applying distribution/ niche modelling techniques as a first pass assessment. Secondand third-pass assessments that integrate the effect of biotic, mobility and temporal factors on mangrove distribution will significantly improve predictive capacity.

Given the need to plan for climate change, it is imperative that mangrove-saltmarsh distribution research moves beyond simple modelling approaches that assume equilibrium between realised and fundamental niches, and ignore spatial and temporal variability. Integration of modelling approaches from various disciplines interested in mangrove distribution is essential if robust conservation strategies are to be implemented that improve adaptation to climate change and maintenance of ecosystem services provided by coastal wetlands.

Acknowledgements This review was supported by the Australian Research Council FT130100532 (for KR), and by the U.S. Geological Survey Climate and Land Use Change Research \& Development Program and U.S. Geological Survey Environments Program (for KWK). Any use of trade, firm, or product names is for descriptive purposes only and does not imply endorsement by the U.S. Government. The authors wish to acknowledge the artwork of Mr. Kieren Northam.

\section{References}

Adams J, Veldkornet D, Tabot P (2016) Distribution of macrophyte species and habitats in south African estuaries. South African Journal of Botany 107:5-11. https://doi.org/10.1016/j.sajb.2016.08.001

Akumu CE, Pathirana S, Baban S et al (2011) Examining the potential impacts of sea level rise on coastal wetlands in north-eastern NSW, Australia. Journal of Coastal Conservation 15:15-22. https://doi. org/10.1007/s11852-010-0114-3

Alleman LK, Hester MW (2011) Refinement of the fundamental niche of black mangrove (Avicennia germinans) seedlings in Louisiana: applications for restoration. Wetlands Ecology and Management 19: 47-60. https://doi.org/10.1007/s11273-010-9199-6

Andrews TJ, Clough BF, Muller GJ (1984) Photosynthetic gas exchange properties and carbon isotope ratios of some mangroves in North Queensland. In: Teas HJ (ed) Physiology and Management of
Mangroves. Springer, Dordrecht, pp 15-23. https://doi.org/10. 1007/978-94-009-6572-0 2

Araújo MB, Guisan A (2006) Five (or so) challenges for species distribution modelling. Journal of Biogeography 33:1677-1688. https:// doi.org/10.1111/j.1365-2699.2006.01584.x

Armitage AR, Highfield WE, Brody SD et al (2015) The contribution of mangrove expansion to salt marsh loss on the Texas Gulf Coast. PLoS One 10:e0125404. https://doi.org/10.1371/journal.pone. 0125404

Asbridge E, Lucas R, Ticehurst C et al (2016) Mangrove response to environmental change in Australia's Gulf of Carpentaria. Ecology and Evolution 6:3523-3539. https://doi.org/10.1002/ece3.2140

Ball MC (1980) Patterns of secondary succession in a mangrove forest of southern Florida. Oecologia 44:226-235. https://doi.org/10.1007/ BF00572684

Ball MC (1988) Salinity tolerance in the mangroves Aegiceras corniculatum and Avicennia marina. I. Water use in relation to growth, carbon partitioning, and salt balance. Functional Plant Biology 15:447-464. https://doi.org/10.1071/PP9880447

Ball MC, Farquhar GD (1984) Photosynthetic and stomatal responses of two mangrove species, Aegiceras corniculatum and Avicennia marina, to long term salinity and humidity conditions. Plant Physiology 74:1-6. https://doi.org/10.1104/pp.74.1.1

Ball MC, Munns R (1992) Plant responses to salinity under elevated atmospheric concentrations of $\mathrm{CO}_{2}$. Australian Journal of Botany 40:515-525. https://doi.org/10.1071/BT9920515

Ball MC, Sobrado M (1998) Chapter 17. Ecophysiology of mangroves: challenges in linking physiological proceses with patterns in forest structure. In: Press M, Scholes J, Barker M (eds) Physiological plant ecology. Blackwell Science, London, pp 331-346

Ball MC, Cochrane MJ, Rawson HM (1997) Growth and water use of the mangroves Rhizophora apiculata and R. stylosa in response to salinity and humidity under ambient and elevated concentrations of atmospheric $\mathrm{CO}_{2}$. Plant. Cell and Environment 20:1158-1166. https://doi.org/10.1046/j.1365-3040.1997.d01-144.x

Berger U, Rivera-Monroy VH, Doyle TW et al (2008) Advances and limitations of individual-based models to analyze and predict dynamics of mangrove forests: a review. Aquatic Botany 89:260 274. https://doi.org/10.1016/j.aquabot.2007.12.015

Bianchi TS, Allison MA, Zhao J et al (2013) Historical reconstruction of mangrove expansion in the Gulf of Mexico: linking climate change with carbon sequestration in coastal wetlands. Estuarine, Coastal and Shelf Science 119:7-16. https://doi.org/10.1016/j.ecss.2012. 12.007

Boon PI, Allen T, Brook J et al (2011) Mangroves and coastal saltmarsh of Victoria: distribution, condition, threats and management. Victorian Saltmarsh Study, Institute for Sustainability and Innovation, Victoria University, Melbourne, Australia

Bridgewater PB, Cresswell ID (1999) Biogeography of mangrove and saltmarsh vegetation: implications for conservation and management in Australia. Mangroves and Salt Marshes 3:117-125. https://doi.org/10.1023/A:1009905127930

Bucher D, Saenger P (1994) A classification of tropical and subtropical Australian estuaries. Aquatic Conservation: Marine and Freshwater Ecosystems 4:1-19. https://doi.org/10.1002/aqc.3270040102

Burton T (1982) Mangrove changes recorded north of Adelaide. Safic 6: $8-12$

Cavanaugh KC, Kellner JR, Forde AJ et al (2014) Poleward expansion of mangroves is a threshold response to decreased frequency of extreme cold events. Proceedings of the National Academy of Sciences (USA) 111:723-727. https://doi.org/10.1073/pnas. 1315800111

Cavanaugh KC, Parker JD, Cook-Patton SC et al (2015) Integrating physiological threshold experiments with climate modeling to project mangrove species' range expansion. Global Change Biology 21:1928-1938. https://doi.org/10.1111/gcb.12843 
Chandler MEJ (1978) Supplement to the Lower Tertiary floras of Southern England. Part 5, Tertiary Research Special Paper \#4, The Tertiary Research Group, London, UK

Chapman V (1975) Mangrove biogeography. p. 3-22. Proceedings of the International Symposium on Biology and Management of Mangroves. University of Florida Press Gainesville, Florida, USA

Chappell J (1993) Contrasting Holocene sedimentary geologies of lower Daly River, northern Australia, and lower Sepik-Ramu, Papua New Guinea. Sedimentary Geology 83:339-358. https://doi.org/10.1016/ 0037-0738(93)90020-6

Clark JA, Farrell WE, Peltier WR (1978) Global changes in postglacial sea level: a numerical calculation. Quaternary Research 9:265-287. https://doi.org/10.1016/0033-5894(78)90033-9

Clarke PJ (1993) Dispersal of grey mangrove (Avicennia marina) propagules in southeastern Australia. Aquatic Botany 45:195-204. https:// doi.org/10.1016/0304-3770(93)90021-N

Clarke PJ (1995) The population dynamics of the mangrove shrub Aegiceras corniculatum (Myrsinaceae): fecundity, dispersal, establishment and population structure. Proceedings of the Linnean Society of New South Wales 115:35-44

Clarke PJ, Allaway WG (1993) The regeneration niche of the grey mangrove (Avicennia marina): effects of salinity, light and sediment factors on establishment, growth and survival in the field. Oecologia 93:548-556. https://doi.org/10.1007/BF00328964

Clarke LD, Hannon NJ (1970) The mangrove swamp and salt marsh communities of the Sydney District: III. Plant growth in relation to salinity and waterlogging. Journal of Ecology 58:351-369

Clarke P, Myerscough PJ (1991) Buoyancy of Avicennia marina propagules in south-eastern Australia. Australian Journal of Botany 39: 77-83. https://doi.org/10.1071/BT9910077

Clarke PJ, Myerscough PJ (1993) The intertidal distribution of the grey mangrove (Avicennia marina) in southeastern Australia: the effects of physical conditions, interspecific competition, and predation on propagule establishment and survival. Australian Journal of Ecology 18:307-315. https://doi.org/10.1111/j.1442-9993.1993.tb00458.x

Clarke PJ, Kerrigan RA, Westphal CJ (2001) Dispersal potential and early growth in 14 tropical mangroves: do early life history traits correlate with patterns of adult distribution? Journal of Ecology 89:648-659. https://doi.org/10.1046/j.0022-0477.2001.00584.x

Clough BF, Andrews T, Cowan I (1982) Physiological processes in mangroves. In: Clough BF (ed) Mangrove ecosystems in Australia: structure. Function and Management. Australian National University Press, Canberra, pp 193-210

Coldren GA, Proffitt CE (2017) Mangrove seedling freeze tolerance depends on salt marsh presence, species, salinity, and age. Hydrobiologia 803:159-171. https://doi.org/10.1007/s10750-0173175-6

Comeaux RS, Allison MA, Bianchi TS (2012) Mangrove expansion in the Gulf of Mexico with climate change: implications for wetland health and resistance to rising sea levels. Estuarine, Coastal and Shelf Science 96:81-95. https://doi.org/10.1016/j.ecss.2011.10.003

Cook-Patton SC, Lehmann M, Parker JD (2015) Convergence of three mangrove species towards freeze-tolerant phenotypes at an expanding range edge. Functional Ecology 29:1332-1340. https:// doi.org/10.1111/1365-2435.12443

Cowell PJ, Thom BG (1994) Morphodynamics of coastal evolution. In: Carter RWG, Woodrofe CD (eds) Coastal evolution: Late Quaternary shoreline Morphodynamics. Cambridge University Press, Cambridge, pp 33-86

Cronin TM (2012) Rapid Sea-level rise. Quaternary Science Reviews 56: 11-30. https://doi.org/10.1016/j.quascirev.2012.08.021

Dangremond EM, Feller IC (2016) Precocious reproduction increases at the leading edge of a mangrove range expansion. Ecology and Evolution 6:5087-5092. https://doi.org/10.1002/ece3.2270
Davis JH (1940) The ecology and geologic role of mangroves in Florida. Carnegie Institution of Washington Publication No. 517. Papers from the Tortugas. Laboratory 32:307-412

DCC (2009) Climate change risks to Australia's coast: a first pass National Assessment. Department of Climate Change, Canberra

De Vriend HJ (1991) Mathematical modelling and large-scale coastal behaviour: part 1: physical processes. Journal of Hydraulic Research 29:727-740.https://doi.org/10.1080/ 00221689109498955

DNR (2006) Survey of tidal limits and mangrove limits in NSW estuaries: 1996 to 2005. Prepared by Manly Hydraulics Laboratory for the NSW Department of Natural Resources, Australia

Dormann CF, Schymanski SJ, Cabral J et al (2012) Correlation and process in species distribution models: bridging a dichotomy. Journal of Biogeography 39:2119-2131. https://doi.org/10.1111/j.1365-2699. 2011.02659.x

Doughty CL, Langley JA, Walker WS et al (2016) Mangrove range expansion rapidly increases coastal wetland carbon storage. Estuaries and Coasts 39:385-396. https://doi.org/10.1007/s12237015-9993-8

Downton MW, Miller KA (1993) The freeze risk to Florida citrus. Part II: Temperature variability and circulation patterns Journal of Climate 6:364-372. https://doi.org/10.1175/1520-0442(1993)006<0364: TFRTFC $>2.0 . \mathrm{CO} ; 2$

Doyle TW, Krauss KW, Conner WH et al (2010) Predicting the retreat and migration of tidal forests along the northern Gulf of Mexico under sea-level rise. Forest Ecology and Management 259:770 777. https://doi.org/10.1016/j.foreco.2009.10.023

Duever MJ, Meeder JF, Meeder LC et al (1994) The climate of South Florida and its role in shaping the Everglades ecosystem. In: Davis SM, Ogden JC (eds) Everglades: the ecosystem and its restoration. St. Lucie Press, Florida, pp 225-248

Duke NC (1991) A systematic revision of the mangrove genus Avicennia (Avicenniaceae) in Australasia. Australian Systematic Botany 4: 299-324. https://doi.org/10.1071/SB9910299

Duke NC (1995) Genetic diversity, distributional barriers and rafting continents-more thoughts on the evolution of mangroves. Hydrobiologia 295:167-181. https://doi.org/10.1007/BF00029124

Duke NC (2006) Australia's mangroves. University of Queensland, Brisbane

Duke NC, Ball MC, Ellison JC (1998a) Factors influencing biodiversity and distributional gradients in mangroves. Global Ecology and Biogeography Letters 7:27-47. https://doi.org/10.1111/j.14668238.1998.00269.x

Duke NC, Benzie JAH, Goodall JA et al (1998b) Genetic structure and evolution of species in the mangrove genus Avicennia (Avicenniaceae) in the indo-West Pacific. Evolution 52:16121626. https://doi.org/10.1111/j.1558-5646.1998.tb02242.x

Duke NC, Meynecke JO, Dittmann S et al (2007) A world without mangroves? Science 317:41-42. https://doi.org/10.1126/science.317. $5834.41 \mathrm{~b}$

Duke NC, Kovacs JM, Griffiths AD et al (2017) Large-scale dieback of mangroves in Australia's Gulf of Carpentaria: a severe ecosystem response, coincidental with an unusually extreme weather event. Marine and Freshwater Research 68:1816-1829. https://doi.org/10. 1071/MF16322

Dutilleul P (1993) Spatial heterogeneity and the design of ecological field experiments. Ecology 74:1646-1658. https://doi.org/10.2307/ 1939923

Elith J, Phillips SJ, Hastie T et al (2011) A statistical explanation of MaxEnt for ecologists. Diversity and Distributions 17:43-57. https://doi.org/10.1111/j.1472-4642.2010.00725.x

Ellison JC (2008) Long-term retrospection on mangrove development using sediment cores and pollen analysis: a review. Aquatic Botany 89:93-104. https://doi.org/10.1016/j.aquabot.2008.02.007 
Ellison AM, Farnsworth EJ, Merkt RE (1999) Origins of mangrove ecosystems and the mangrove biodiversity anomaly. Global Ecology and Biogeography 8:95-115. https://doi.org/10.1046/j.1466-822X. 1999.00126.x

Enwright NM, Griffith KT, Osland MJ (2016) Barriers to and opportunities for landward migration of coastal wetlands with sea-level rise. Frontiers in Ecology and the Environment 14:307-316. https://oi. org/10.1002/fee. 1282

Eslami-Andargoli L, Dale P, Sipe N et al (2009) Mangrove expansion and rainfall patterns in Moreton Bay, Southeast Queensland, Australia. Estuarine, Coastal and Shelf Science 85:292-298. https://doi.org/10. 1016/j.ecss.2009.08.011

Evans MW, Hine AC, Belknap DF et al (1985) Bedrock controls on barrier island development: west-Central Florida coast. Marine Geology 63:263-283. https://doi.org/10.1016/0025-3227(85) 90086-6

Farnsworth EJ, Ellison AM, Gong WK (1996) Elevated $\mathrm{CO}_{2}$ alters anatomy, physiology, growth and reproduction of red mangroves (Rhizophora mangle L.). Oecologia 108:599-609. https://doi.org/ 10.1007/BF00329032

Franklin J (2010) Moving beyond static species distribution models in support of conservation biogeography. Diversity and Distributions 16:321-330. https://doi.org/10.1111/j.1472-4642.2010.00641.x

Friess DA, Krauss KW, Horstman EM et al (2012) Are all intertidal wetlands naturally created equal? Bottlenecks, thresholds and knowledge gaps to mangrove and saltmarsh ecosystems. Biological Reviews 87:346-366. https://doi.org/10.1111/j.1469185X.2011.00198.x

Galloway RW (1982) Distribution and physiographic patterns of Australian mangroves. In: Clough BF (ed) Mangrove ecosystems in Australia. Australian Institute of Marine Science and ANU Press, Canberra, pp 31-54

Gee CT (2001) The mangrove palm Nypa in the geologic past of the New World. Wetlands Ecology and Management 9:181-203. https://doi. org/10.1023/A:1011148522181

Geosciences Australia (2011) Ozcoasts: Australian online coastal information. Geosciences Australia, Canberra

Geselbracht L, Freeman K, Kelly E et al (2011) Retrospective and prospective model simulations of sea level rise impacts on Gulf of Mexico coastal marshes and forests in Waccasassa Bay, Florida. Climatic Change 107:35-57. https://doi.org/10.1007/s10584-0110084-y

Geselbracht LL, Freeman K, Birch AP et al (2015) Modeled Sea level rise impacts on coastal ecosystems at six major estuaries on Florida's Gulf Coast: implications for adaptation planning. PLoS One 10: e0132079. https://doi.org/10.1371/journal.pone.0132079

Giampietro M (1994) Using hierarchy theory to explore the concept of sustainable development. Futures 26:616-625. https://doi.org/10. 1016/0016-3287(94)90033-7

Giri CP, Long J (2014) Mangrove reemergence in the northernmost range limit of eastern Florida. Proceedings of the National Academy of Sciences (USA) 111:E1447-E1448. https://doi.org/10.1073/pnas. 1400687111

Giri C, Long J (2016) Is the geographic range of mangrove forests in the conterminous United States really expanding? Sensors 16:2010. https://doi.org/10.3390/s16122010

Giri C, Long J, Tieszen L (2011a) Mapping and monitoring Louisiana's mangroves in the aftermath of the 2010 Gulf of Mexico oil spill. Journal of Coastal Research 27:1059-1064. https://doi.org/10.2112/ JCOASTRES-D-11-00028.1

Giri C, Ochieng E, Tieszen LL et al (2011b) Status and distribution of mangrove forests of the world using earth observation satellite data. Global Ecology and Biogeography 20:154-159. https://doi.org/10. $1111 / j .1466-8238.2010 .00584 . x$
Gostin VA, Hails JR, Belperio AP (1984) The sedimentary framework of northern Spencer gulf, South Australia. Marine Geology 61:111138. https://doi.org/10.1016/0025-3227(84)90164-6

Guisan A, Thuiller W (2005) Predicting species distribution: offering more than simple habitat models. Ecology Letters 8:993-1009. https://doi.org/10.1111/j.1461-0248.2005.00792.x

Guisan A, Lehmann A, Ferrier S et al (2006) Making better biogeographical predictions of species' distributions. Journal of Applied Ecology 43:386-392. https://doi.org/10.1111/j.1365-2664.2006.01164.x

Guo H, Zhang Y, Lan Z et al (2013) Biotic interactions mediate the expansion of black mangrove (Avicennia germinans) into salt marshes under climate change. Global Change Biology 19:27652774. https://doi.org/10.1111/gcb.12221

Haines PE (2006) Physical and chemical behaviour and management of Intermittently closed and open lakes and lagoons (ICOLL's) in NSW. Doctor of Philosophy PhD, Griffith University, Brisbane

Haines PE, Tomlinson RB, Thom BG (2006) Morphometric assessment of intermittently open/closed coastal lagoons in New South Wales, Australia. Estuarine, Coastal and Shelf Science 67:321-332. https:// doi.org/10.1016/j.ecss.2005.12.001

Hamilton SE, Casey D, Field R (2016) Creation of a high spatio-temporal resolution global database of continuous mangrove forest cover for the 21st century (CGMFC-21). Global Ecology and Biogeography 25:729-738. https://doi.org/10.1111/geb.12449

Hashimoto TR, Saintilan N, Haberle SG (2006) Mid-Holocene development of mangrove communities featuring Rhizophoraceae and geomorphic change in the Richmond River estuary, New South Wales, Australia. Geographical Research 44:63-76. https://doi.org/10. $1111 / \mathrm{j} .1745-5871.2006 .00360 . x$

Henry KM, Twilley RR (2013) Soil development in a coastal Louisiana wetland during a climate-induced vegetation shift from salt marsh to mangrove. Journal of Coastal Research 29:1273-1283. https://doi. org/10.2112/jcoastres-d-12-00184.1

Hijmans RJ, Graham CH (2006) The ability of climate envelope models to predict the effect of climate change on species distributions. Global Change Biology 12:2272-2281. https://doi.org/10.1111/j. 1365-2486.2006.01256.x

Hine AC, Belknap DF, Hutton JG et al (1988) Recent geological history and modern sedimentary processes along an incipient, low-energy, epicontinental-sea coastline: Northwest Florida. Journal of Sedimentary Research 58:567-579

IUCN Red List (2017) IUCN Red List spatial data for mangroves. International Union for Conservation of Nature

Jarnevich CS, Stohlgren TJ, Kumar S et al (2015) Caveats for correlative species distribution modeling. Ecological Informatics 29(1):6-15. https://doi.org/10.1016/j.ecoinf.2015.06.007

Jiménez-Valverde A, Lobo JM, Hortal J (2008) Not as good as they seem: the importance of concepts in species distribution modelling. Diversity and Distributions 14:885-890. https://doi.org/10.1111/j. 1472-4642.2008.00496.x

Jones RL (1990) Late Holocene vegetational changes on the Illawarra coastal plain, New South Wales, Australia. Review of Palaeobotany and Palynology 65:37-46. https://doi.org/10.1016/0034-6667(90) 90054-M

Jones BG, Youngt RW, Eliot IG (1979) Stratigraphy and chronology of receding barrier-beach deposits on the northern Illawarra coast of New South Wales. Journal of the Geological Society of Australia 26: 255-264. https://doi.org/10.1080/00167617908729089

Jones SF, Stagg CL, Krauss KW et al (2016) Tidal saline wetland regeneration of sentinel vegetation types in the northern Gulf of Mexico: an overview. Estuarine, Coastal and Shelf Science 174:A1-A10. https://doi.org/10.1016/j.ecss.2016.02.010

Kelleway JJ, Saintilan N, Macreadie PI et al (2016) Seventy years of continuous encroachment substantially increases 'blue carbon'capacity as mangroves replace intertidal salt marshes. 
Global Change Biology 22:1097-1109. https://doi.org/10.1111/gcb. 13158

Knighton AD, Mills K, Woodroffe CD (1991) Tidal-creek extension and saltwater intrusion in northern Australia. Geology 19:831-834. https://doi.org/10.1130/0091-7613(1991)019<0831:tceasi>2.3.co;2

Kramer-Schadt S, Niedballa J, Pilgrim JD et al (2013) The importance of correcting for sampling bias in MaxEnt species distribution models. Diversity and Distributions 19:1366-1379. https://doi.org/10.1111/ ddi. 12096

Krauss KW, Doyle TW, Twilley RR et al (2006) Evaluating the relative contributions of hydroperiod and soil fertility on growth of South Florida mangroves. Hydrobiologia 569:311-324. https://doi.org/10. 1007/s10750-006-0139-7

Krauss KW, Lovelock CE, McKee KL et al (2008) Environmental drivers in mangrove establishment and early development: a review. Aquatic Botany 89:105-127. https://doi.org/10.1016/j.aquabot. 2007.12.014

Krauss KW, From AS, Doyle TW et al (2011) Sea-level rise and landscape change influence mangrove encroachment onto marsh in the ten Thousand Islands region of Florida, USA. Journal of Coastal Conservation 15:629-638. https://doi.org/10.1007/s11852-0110153-4

Krauss KW, McKee KL, Hester MW (2014) Water use characteristics of black mangrove (Avicennia germinans) communities along an ecotone with marsh at a northern geographical limit. Ecohydrology 7: 354-365. https://doi.org/10.1002/eco.1353

Ladd H (1965) Tertiary fresh-water mollusks from Pacific Islands. Malacologia 2:189-197

Langley JA, McKee KL, Cahoon DR et al (2009) Elevated $\mathrm{CO}_{2}$ stimulates marsh elevation gain, counterbalancing sea-level rise. Proceedings of the National Academy of Sciences (USA) 106: 6182-6186. https://doi.org/10.1073/pnas.0807695106

Leopold EB (1969) Miocene pollen and spore Flora of Eniwetok atoll, Marshall Islands. US Government Printing Office, Washington, DC

Lewis R, Dunstan F (1975) The possible role of Spartina alterniflora Loisel in establishment of mangroves in Florida. p. 82-100. Proceedings for Second Annual Conference on the Restoration of Coastal Vegetation in Florida May 17, 1975, Hillsborough Community College, Tampa, Florida, USA

Lovelock C, Grinham A, Adame MF et al (2010) Elemental composition and productivity of cyanobacterial mats in an arid zone estuary in North Western Australia. Wetlands Ecology and Management 18: 37-47. https://doi.org/10.1007/s11273-009-9146-6

Lovelock CE, Ruess RW, Feller IC (2011) $\mathrm{CO}_{2}$ efflux from cleared mangrove peat. PLoS One 6:e21279. https://doi.org/10.1371/journal. pone.0021279

Lovelock CE, Reef R, Ball MC (2017) Isotopic signatures of stem water reveal differences in water sources accessed by mangrove tree species. Hydrobiologia 803:133-145. https://doi.org/10.1007/s10750017-3149-8

Lucas R, Finlayson CM, Bartolo R et al (2018) Historical perspectives on the mangroves of Kakadu National Park. Marine and Freshwater Research 69:1047-1063. https://doi.org/10.1071/MF17065

Lugo AE, Snedaker SC (1974) The ecology of mangroves. Annual Review of Ecology and Systematics 5:39-64

Madrid EN, Armitage AR, López-Portillo J (2014) Avicennia germinans (black mangrove) vessel architecture is linked to chilling and salinity tolerance in the Gulf of Mexico. Frontiers in Plant Science 5:503. https://doi.org/10.3389/fpls.2014.00503

Maguire TL, Saenger P, Baverstock P et al (2000) Microsatellite analysis of genetic structure in the mangrove species Avicennia marina (Forsk.) Vierh. (Avicenniaceae). Molecular Ecology 9:1853-1862. https://doi.org/10.1046/j.1365-294x.2000.01089.x

Markley JL, McMillan C, Thompson GA Jr (1982) Latitudinal differentiation in response to chilling temperatures among populations of three mangroves, Avicennia germinans, Laguncularia racemosa, and Rhizophora mangle, from the western tropical Atlantic and Pacific Panama. Canadian Journal of Botany 60:2704-2715. https://doi.org/10.1139/b82-330

McCally D (1999) The Everglades: an environmental history. University Press of Florida, Gainesville

McKee KL (2011) Biophysical controls on accretion and elevation change in Caribbean mangrove ecosystems. Estuarine, Coastal and Shelf Science 91:475-483. https://doi.org/10.1016/j.ecss.2010.05. 001

McKee KL, Rooth JE (2008) Where temperate meets tropical: multifactorial effects of elevated $\mathrm{CO}_{2}$, nitrogen enrichment, and competition on a mangrove-salt marsh community. Global Change Biology 14:971-984. https://doi.org/10.1111/j.1365-2486.2008. 01547.x

McKee KL, Vervaeke WC (2018) Will fluctuations in salt marsh-mangrove dominance alter vulnerability of a subtropical wetland to sealevel rise? Global Change Biology 24:1224-1238. https://doi.org/ $10.1111 /$ gcb. 13945

McKee KL, Cahoon DR, Feller IC (2007) Caribbean mangroves adjust to rising sea level through biotic controls on change in soil elevation. Global Ecology and Biogeography 16:545-556. https://doi.org/10. $1111 / j .1466-8238.2007 .00317 . x$

McKee KL, Rogers K, Saintilan N (2012) Response of salt marsh and mangrove wetlands to changes in atmospheric $\mathrm{CO}_{2}$, climate, and sea level. In: Middleton BA (ed) Global change and the function and distribution of wetlands. Springer, Netherlands, pp 63-96. https:// doi.org/10.1007/978-94-007-4494-3_2

McLoughlin L (2000) Estuarine wetlands distribution along the Parramatta River, Sydney, 1788-1940: implications for planning and conservation. Cunninghamia 6:579-610 http://hdl.handle.net/ $1959.14 / 1097068$

McMillan C (1986) Isozyme patterns among populations of black mangrove Avicennia germinans, from the Gulf of Mexico-Caribbean and Pacific Panama. Contributions in Marine Science 29:17-25

McMillan C, Sherrod CL (1986) The chilling tolerance of black mangrove, Avicennia germinans, from the Gulf of Mexico coast of Texas, Louisiana and Florida. Contributions in Marine Science 29: 9-16

Mcowen C, Weatherdon L, Bochove J-W et al (2017) A global map of saltmarshes. Biodiversity Data Journal 5:e11764. https://doi.org/10. 3897/BDJ.5.e11764

Middleton BA, McKee KL (2001) Degradation of mangrove tissues and implications for peat formation in Belizean island forests. Journal of Ecology 89:818-828. https://doi.org/10.1046/j.0022-0477.2001. 00602.x

Milliken KT, Anderson JB, Rodriguez AB (2008) A new composite Holocene Sea-level curve for the northern Gulf of Mexico. Geological Society of America Special Papers 443:1-11. https:// doi.org/10.1130/2008.2443(01)

Mogensen LA, Rogers K (2018) Validation and comparison of a model of the effect of sea-level rise on coastal wetlands. Scientific Reports 8: 1369. https://doi.org/10.1038/s41598-018-19695-2

Moldenke HN (1960) Materials towards a monograph of the genus Avicennia. I, II \& III. Phytologia 7:123-193

Montague CL, Odum HT (1997) The intertidal marshes of Florida's Gulf Coast. In: Coultas CL, Hsieh Y (eds) Ecology and Management of Tidal Marshes: a model from the Gulf of Mexico. St Lucie Press, Delroy Beach, pp 1-9

Montague CL, Wiegert RG (1990) Salt marshes. In: Myers RL, Ewel JJ (eds) Ecosystems of Florida. University of Central Florida Press, Orlando, pp 481-516

Mulrennan ME, Woodroffe CD (1998) Saltwater intrusion into the coastal plains of the lower Mary River, Northern Territory, Australia. Journal of Environmental Management 54:169-188. https://doi. org/10.1006/jema.1998.0229 
Murray-Wallace CV, Woodroffe CD (2014) Quaternary Sea-level changes: a global perspective. Cambridge University Press, Cambridge

Nicholls N, Collins D (2006) Observed climate change in Australia over the past century. Energy \& Environment 17:1-12

Nunes R, Lennon G (1986) Physical property distributions and seasonal trends in Spencer gulf, South Australia: an inverse estuary. Australian Journal of Marine \& Freshwater Research 37:39-53. https://doi.org/10.1071/MF9860039

Oliver T, Rogers K, Chafer C et al (2012) Measuring, mapping and modelling: an integrated approach to the management of mangrove and saltmarsh in the Minnamurra River estuary, Southeast Australia. Wetlands Ecology and Management 20:353-371. https://doi.org/10. 1007/s11273-012-9258-2

O'Neill RV (1986) A hierarchical concept of ecosystems. Princeton University Press, Princeton

Osland MJ, Enwright N, Day RH et al (2013) Winter climate change and coastal wetland foundation species: salt marshes vs. mangrove forests in the southeastern United States. Global Change Biology 19: 1482-1494. https://doi.org/10.1111/gcb.12126

Osland MJ, Day RH, From AS et al (2015) Life stage influences the resistance and resilience of black mangrove forests to winter climate extremes. Ecosphere 6:1-15. https://doi.org/10.1890/ES15-00042.1

Osland MJ, Enwright NM, Day RH et al (2016) Beyond just sea-level rise: considering macroclimatic drivers within coastal wetland vulnerability assessments to climate change. Global Change Biology 22:1-11. https://doi.org/10.1111/gcb.13084

Osland MJ, Day RH, Hall CT et al (2017) Mangrove expansion and contraction at a poleward range limit: climate extremes and landocean temperature gradients. Ecology 98:125-137. https://doi.org/ 10.1002/ecy. 1625

Parkinson RW (1989) Decelerating Holocene Sea-level rise and its influence on Southwest Florida coastal evolution; a transgressive/ regressive stratigraphy. Journal of Sedimentary Research 59:960 972. https://doi.org/10.1306/212F90C5-2B24-11D7$8648000102 \mathrm{C} 1865 \mathrm{D}$

Parkinson RW, DeLaune RD, White JR (1994) Holocene Sea-level rise and the fate of mangrove forests within the wider Caribbean region. Journal of Coastal Research 10:1077-1086

Patterson CS, Mendelssohn IA (1991) A comparison of physicochemical variables across plant zones in a mangal/salt marsh community in Louisiana. Wetlands 11:139-161. https://doi.org/10.1007/ BF03160845

Patterson CS, Mendelssohn IA, Swenson EM (1993) Growth and survival of Avicennia germinans seedlings in a mangal/salt marsh community in Louisiana, USA. Journal of Coastal Research 9:801-810

Patterson S, McKee KL, Mendelssohn IA (1997) Effects of tidal inundation and predation on Avicennia germinans seedling establishment and survival in a sub-tropical mangal/salt marsh community. Mangroves and Salt Marshes 1:103-111. https://doi.org/10.1023/ A:1009923917812

Pearson RG, Dawson TP (2003) Predicting the impacts of climate change on the distribution of species: are bioclimate envelope models useful? Global Ecology and Biogeography 12:361-371. https://doi.org/ 10.1046/j.1466-822X.2003.00042.x

Penfound WT, Hathaway ES (1938) Plant communities in the marshlands of southeastern Louisiana. Ecological Monographs 8:1-56. https:// doi.org/10.2307/1943020

Perry CL, Mendelssohn IA (2009) Ecosystem effects of expanding populations of Avicennia germinans in a Louisiana salt marsh. Wetlands 29:396-406. https://doi.org/10.1672/08-100.1

Peterson JM, Bell SS (2012) Tidal events and salt-marsh structure influence black mangrove (Avicennia germinans) recruitment across an ecotone. Ecology 93:1648-1658. https://doi.org/10.1890/11-1430.1

Peterson AT, Soberón J (2012a) Integrating fundamental concepts of ecology, biogeography, and sampling into effective ecological niche modeling and species distribution modeling. Plant Biosystems 146: 789-796. https://doi.org/10.1080/11263504.2012.740083

Peterson AT, Soberón J (2012b) Species distribution modeling and ecological niche modeling: getting the concepts right. Natureza \& Conservação 10:102-107

Pickens CN, Hester MW (2011) Temperature tolerance of early life history stages of black mangrove Avicennia germinans: implications for range expansion. Estuaries and Coasts 34:824-830. https://doi. org/10.1007/s12237-010-9358-2

Plaziat J, Cavagnetto C (1996) Taphonomic and biogeographic processes controlling the mangrove trees and mollusk association of the Pyrenean Paleocene and Eocene. p. 331-336. In Comunicación de la II Reunion de Tafonomia y Fosilizacion

Plaziat J-C, Cavagnetto C, Koeniguer J-C et al (2001) History and biogeography of the mangrove ecosystem, based on a critical reassessment of the paleontological record. Wetlands Ecology and Management 9:161-180. https://doi.org/10.1023/A: 1011118204434

Pole MS, Macphail MK (1996) Eocene Nypa from regatta point, Tasmania. Review of Palaeobotany and Palynology 92:55-67. https://doi.org/10.1016/0034-6667(95)00099-2

Quinn GP, Keough MJ (2002) Experimental design and data analysis for biologists. Cambridge University Press, Cambridge

Quisthoudt K, Schmitz N, Randin C et al (2012) Temperature variation among mangrove latitudinal range limits worldwide. Trees 26: 1919-1931. https://doi.org/10.1007/s00468-012-0760-1

Quisthoudt K, Adams J, Rajkaran A et al (2013) Disentangling the effects of global climate and regional land-use change on the current and future distribution of mangroves in South Africa. Biodiversity and Conservation 22:1369-1390. https://doi.org/10.1007/s10531-0130478-4

Raabe EA, Roy LC, McIvor CC (2012) Tampa Bay coastal wetlands: nineteenth to twentieth century tidal marsh-to-mangrove conversion. Estuaries and Coasts 35:1145-1162. https://doi.org/10.1007/ s12237-012-9503-1

Recher HF, Hutchings PA, Rosen S (1993) The biota of the HawkesburyNepean catchment: reconstruction and restoration. Australian Zoologist 29:3-41. https://doi.org/10.7882/AZ.1993.002

Record S, Charney ND, Zakaria RM et al (2013) Projecting global mangrove species and community distributions under climate change. Ecosphere 4:1-23. https://doi.org/10.1890/ES12-00296.1

Richards DR, Friess DA (2016) Rates and drivers of mangrove deforestation in Southeast Asia, 2000-2012. Proceedings of the National Academy of Sciences (USA) 113:344-349. https://doi.org/10.1073/ pnas. 1510272113

Richey JN, Poore RZ, Flower BP et al (2007) 1400 yr multiproxy record of climate variability from the northern Gulf of Mexico. Geology 35: 423-426. https://doi.org/10.1130/G23507A.1

Rodriguez W, Feller IC, Cavanaugh KC (2016) Spatio-temporal changes of a mangrove-saltmarsh ecotone in the northeastern coast of Florida, USA. Global Ecology and Conservation 7:245-261. https://doi.org/10.1016/j.gecco.2016.07.005

Rogers K (2004) Mangrove and saltmarsh surface elevation dynamics in relation to environmental variables in southeastern Australia. $\mathrm{PhD}$ Thesis, University of Wollongong, Wollongong, Australia

Rogers K, Saintilan N (2009) Relationships between surface elevation and groundwater in mangrove forests of Southeast Australia. Journal of Coastal Research 24:63-69. https://doi.org/10.2112/050519.1

Rogers K, Saintilan N, Cahoon D (2005) Surface elevation dynamics in a regenerating mangrove forest at Homebush Bay, Australia. Wetlands Ecology and Management 13:587-598. https://doi.org/ 10.1007/s11273-004-0003-3

Rogers K, Wilton KM, Saintilan N (2006) Vegetation change and surface elevation dynamics in estuarine wetlands of Southeast Australia. 
Estuarine, Coastal and Shelf Science 66:559-569. https://doi.org/10. 1016/j.ecss.2005.11.004

Rogers K, Saintilan N, Copeland C (2012) Modelling wetland surface elevation dynamics and its application to forecasting the effects of sea-level rise on estuarine wetlands. Ecological Modelling 244:148 157. https://doi.org/10.1016/j.ecolmodel.2012.06.014

Rogers K, Saintilan N, Copeland C (2013) Managed retreat of saline coastal wetlands: challenges and opportunities identified from the Hunter River estuary, Australia. Estuaries and Coasts 37:67-78. https://doi.org/10.1007/s12237-013-9664-6

Rogers K, Saintilan N, Woodroffe CD (2014) Surface elevation change and vegetation distribution dynamics in a subtropical coastal wetland: implications for coastal wetland response to climate change. Estuarine, Coastal and Shelf Science 149:46-56. https://doi.org/10. 1016/j.ecss.2014.07.009

Rogers K, Boon PI, Branigan S et al (2016) The state of legislation and policy protecting Australia's mangrove and salt marsh and their ecosystem services. Marine Policy 72:139-155. https://doi.org/10. 1016/j.marpol.2016.06.025

Ross MS, O'Brien JJ, Sternberg LSL (1994) Sea-level rise and the reduction in pine forests in the Florida keys. Ecological Applications 4: 144-156. https://doi.org/10.2307/1942124

Roy PS, Williams RJ, Jones AR et al (2001) Structure and function of south-east Australian estuaries. Estuarine, Coastal and Shelf Science 53:351-384. https://doi.org/10.1006/ecss.2001.0796

Runting RK, Lovelock CE, Beyer HL et al (2016) Costs and opportunities for preserving coastal wetlands under sea level rise. Conservation Letters 10:49-57. https://doi.org/10.1111/conl.12239

Saenger P (1998) Mangrove vegetation: an evolutionary perspective. Marine and Freshwater Research 49:277-286. https://doi.org/10. 1071/MF97139

Saenger P (2002) Mangrove ecology, Silviculture and conservation. Kluwer Academic Press, Dordrecht

Saintilan N (2003) The influence of nutrient enrichment upon mangrove seedling establishment and growth int he Hawkesbury River estuary, New South Wales, Australia. Wetlands (Australia) 21:29-35

Saintilan N, Hashimoto TR (1999) Mangrove-saltmarsh dynamics on a bay-head delta in the Hawkesbury River estuary, New South Wales, Australia. Hydrobiologia 413:95-102. https://doi.org/10.1007/97894-011-4078-2_10

Saintilan N, Rogers K (2013) The significance and vulnerability of Australian saltmarshes: implications for management in a changing climate. Marine and Freshwater Research 64:66-79. https://doi.org/ 10.1071/MF12212

Saintilan N, Rogers K (2015) Woody plant encroachment of grasslands: a comparison of terrestrial and wetland settings. The New Phytologist 205:1062-1070. https://doi.org/10.1111/nph.13147

Saintilan N, Williams RJ (1999) Mangrove transgression into saltmarsh environments in south-East Australia. Global Ecology and Biogeography 8:117-124. https://doi.org/10.1046/j.1365-2699. 1999.00133.x

Saintilan N, Wilson NC, Rogers K et al (2014) Mangrove expansion and salt marsh decline at mangrove poleward limits. Global Change Biology 20:147-157. https://doi.org/10.1111/gcb.12341

Saintilan N, Rogers K, Toms C et al (2016) Intermittent estuaries: linking hydro-geomorphic context to climate change resilience. Journal of Coastal Research, SI 75:133-137. https://doi.org/10.2112/SI75-027. 1

Savage T (1972) Florida Mangroves as Shoreline Stabilizers. Florida Department of Natural Resources Professional Paper 19, Tallahassee, Florida, USA

Schaeffer-Novelli Y, Cintrón-Molero G, Soares M et al (2000) Brazilian mangroves. Aquatic Ecosystem Health \& Management 3:561-570. https://doi.org/10.1016/S1463-4988(00)00052-X

Schrank E (1987) Paleozoic and Mesozoic palynomorphs from Northeast Africa (Egypt and Sudan) with special reference to late cretaceous pollen and dinoflagellates. Berliner Geowissenschaftliche Abhandlungen A 75:249-310

Semeniuk V (1983) Mangrove distribution in northwestern Australia in relationship to regional and local freshwater seepage. Vegetatio 53: 11-31. https://doi.org/10.1007/BF00039767

Semeniuk V (2013) Predicted response of coastal wetlands to climate changes: a western Australian model. Hydrobiologia 708:23-43. https://doi.org/10.1007/s10750-012-1159-0

Sherrod CL, McMillan C (1985) The distributional history and ecology of mangrove vegetation along the northern Gulf of Mexico coastal region. Contributions in Marine Science 28:129-140

Sherwood ET, Greening HS (2014) Potential impacts and management implications of climate change on Tampa Bay estuary critical coastal habitats. Environmental Management 53:401-415. https://doi.org/ 10.1007/s00267-013-0179-5

Sloss CR, Murray-Wallace CV, Jones BG (2007) Holocene Sea-level change on the southeast coast of Australia: a review. Holocene 17: 999-1014

Smith TJ III (1987) Effects of light and intertidal position on seedling survival and growth in tropical tidal forests. Journal of Experimental Marine Biology and Ecology 110:133-146. https://doi.org/10.1016/ 0022-0981(87)90024-4

Smith TJ III, Foster AM, Tiling-Range G et al (2013) Dynamics of mangrove-marsh ecotones in subtropical coastal wetlands: fire, sea-level rise, and water levels. Fire Ecology 9:66-77

Stapor F, Mathews T, Lindfors-Kearns F (1988) Episodic barrier island growth in Southwest Florida: a response to fluctuating Holocene Sea level. Miami Geological Society Memoir 3:149-202

Stevens PW, Fox SL, Montague CL (2006) The interplay between mangroves and saltmarshes at the transition between temperate and subtropical climate in Florida. Wetlands Ecology and Management 14: 435-444. https://doi.org/10.1007/s11273-006-0006-3

Stuart SA, Choat B, Martin KC et al (2007) The role of freezing in setting the latitudinal limits of mangrove forests. The New Phytologist 173: 576-583. https://doi.org/10.1111/j.1469-8137.2006.01938.x

Teas HJ, Wanless HR, Chardon RE (1976) Effects of man on the shore vegetation of Biscayne Bay. In: Thorhaug A, Volker A (eds) Biscayne Bay: past/present/future. University of Miami Press, Coral Gables, pp 133-156

Temmerman S, Govers G, Wartel S et al (2003) Spatial and temporal factors controlling short-term sedimentation in a salt and freshwater tidal marsh, Scheldt estuary, Belgium, SW Netherlands. Earth Surface Processes and Landforms 28:739-755. https://doi.org/10. 1002/esp.495

Terwindt J, Battjes J (1991) Research on large-scale coastal behaviour. p. 1975-1983. Coastal Engineering 1990, Proceedings of the 22nd International Conference on Coastal Engineering. https://doi.org/ $10.1061 / 9780872627765.151$

Thom BG (1984) Coastal landforms and geomorphic processes. Monographs on Oceanographic Methodology 8:3-17

Thom BG, Wright L, Coleman JM (1975) Mangrove ecology and deltaicestuarine geomorphology: Cambridge gulf-Ord River, Western Australia. Journal of Ecology 63:203-232. https://doi.org/10.2307/ 2258851

Thuiller W, Lafourcade B, Engler R et al (2009) BIOMOD-a platform for ensemble forecasting of species distributions. Ecography 32:369 373. https://doi.org/10.1111/j.1600-0587.2008.05742.x

Traill LW, Perhans K, Lovelock CE et al (2011) Managing for change: wetland transitions under sea-level rise and outcomes for threatened species. Diversity and Distributions 17:1225-1233. https://doi.org/ 10.1111/j.1472-4642.2011.00807.x

Twilley RR, Rivera-Monroy VH (2009) Ecogeomorphic models of nutrient biogeochemistry for mangrove wetlands. In: Perillo GME, Wolanski E, Cahoon DR, Brinson MM (eds) Coastal wetlands: an integrated ecosystem approach. Elsevier, Amsterdam, pp 641-683 
Twilley RR, Rivera-Monroy VH, Chen R et al (1999) Adapting an ecological mangrove model to simulate trajectories in restoration ecology. Marine Pollution Bulletin 37:404-419. https://doi.org/10.1016/ S0025-326X(99)00137-X

Twilley RR, Bentley SJ, Chen Q et al (2016) Co-evolution of wetland landscapes, flooding, and human settlement in the Mississippi River Delta plain. Sustainability Science 11:711-731. https://doi.org/10. 1007/s11625-016-0374-4

Vanderzee MP (1988) Changes in saltmarsh vegetation as an early indicator of sea-level rise. In: Pearmen GI (ed) Greenhouse: planning for climate change. CSIRO, Melbourne, pp 147-160

Watson AM (1986) Nutrient-production relations at seahorse key lagoon. Some Consequences of Shorebird Accumulations. MS Thesis, University of Florida, Gainesville, Florida, USA, Florida

Wells AG (1983) Distribution of mangroves species in Australia. In: Teas HJ (ed) Biology and ecology of mangroves. Springer, Dordrecht, pp 57-76. https://doi.org/10.1007/978-94-017-0914-9_6

West RC (1956) Mangrove swamps of the Pacific coast of Colombia. Annals of the Association of American Geographers 46:98-121. https://doi.org/10.1111/j.1467-8306.1956.tb01498.x

Westgate JW, Gee CT (1990) Paleoecology of a middle Eocene mangrove biota (vertebrates, plants, and invertebrates) from Southwest Texas. Palaeogeography Palaeoclimatology Palaeoecology 78:163-177. https://doi.org/10.1016/0031-0182(90)90210-X

White NJ, Haigh ID, Church JA et al (2014) Australian sea levelstrends, regional variability and influencing factors. Earth Science Reviews 136:155-174. https://doi.org/10.1016/j.earscirev.2014.05. 011

Wiens JA (1989) Spatial scaling in ecology. Functional Ecology 3:385397. https://doi.org/10.2307/2389612

Wiens JJ, Donoghue MJ (2004) Historical biogeography, ecology and species richness. Trends in Ecology \& Evolution 19:639-644. https://doi.org/10.1016/j.tree.2004.09.011

Williams AA, Eastman SF, Eash-Loucks WE et al (2014) Record northernmost endemic mangroves on the United States Atlantic Coast with a note on latitudinal migration. Southeastern Naturalist 13: 56-63. https://doi.org/10.1656/058.013.0104

Williamson G, Boggs G, Bowman D (2011) Late 20th century mangrove encroachment in the coastal Australian monsoon tropics parallels the regional increase in woody biomass. Regional Environmental Change 11:19-27. https://doi.org/10.1007/s10113-010-0109-5

Wilson NC (2009) The distribution, growth, reproduction and population genetics of a mangroves species Rhizophora stylosa Griff, near its southern limits in NSW Australia. PhD Thesis, Australian Catholic University, North Sydney, Australia. doi:https://doi.org/10.4226/66/ 5a95eea7c6807

Wilson NC, Saintilan N (2012) Growth of the mangrove species Rhizophora stylosa Griff. At its southern latitudinal limit in eastern
Australia. Aquatic Botany 101:8-17. https://doi.org/10.1016/j. aquabot.2012.03.011

Winn KO, Saynor MJ, Eliot MJ et al (2006) Saltwater intrusion and morphological change at the mouth of the east Alligator River, Northern Territory. Journal of Coastal Research 22:137-149. https://doi.org/10.2112/05a-0011.1

Woodroffe CD (1990) The impact of sea-level rise on mangrove shorelines. Progress in Physical Geography 14:483-520. https://doi.org/ $10.1177 / 030913339001400404$

Woodroffe C (1992) Mangrove sediments and geomorphology. In: Robertson AI, Alongi DM (eds) Tropical mangrove ecosystems. American Geophysical Union, Washington, DC, pp 7-41. https:// doi.org/10.1029/CE041p0007

Woodroffe CD (1995) Response of tide-dominated mangrove shorelines in northern Australia to anticipated sea-level rise. Earth Surface Processes and Landforms 20:65-85. https://doi.org/10.1002/esp. 3290200107

Woodroffe CD, Grindrod J (1991) Mangrove biogeography: the role of quaternary environmental and sea-level change. Journal of Biogeography 18:479-492. https://doi.org/10.2307/2845685

Woodroffe CD, Murray-Wallace CV (2012) Sea-level rise and coastal change: the past as a guide to the future. Quaternary Science Reviews 54:4-11. https://doi.org/10.1016/j.quascirev.2012.05.009

Woodroffe CD, Thom BG, Chappell J (1985) Development of widespread mangrove swamps in mid-Holocene times in northern Australia. Nature 317:711-713. https://doi.org/10.1038/317711a0

Woodroffe CD, Mulrennan ME, Chappell J (1993) Estuarine infill and coastal progradation, southern van Diemen gulf, northern Australia. Sedimentary Geology 83:257-275. https://doi.org/10.1016/00370738(93)90016-X

Wright LD, Thom BG (1977) Coastal depositional landforms: a morphodynamic approach. Progress in Physical Geography: Earth and Environment 1:412-459. https://doi.org/10.1177/ 030913337700100302

Ximenes A, Maeda E, Arcoverde G et al (2016) Spatial assessment of the bioclimatic and environmental factors driving mangrove tree species' distribution along the Brazilian coastline. Remote Sensing 8: 451. https://doi.org/10.3390/rs8060451

Yando ES, Osland MJ, Willis JM et al (2016) Salt marsh-mangrove ecotones: using structural gradients to investigate the effects of woody plant encroachment on plant-soil interactions and ecosystem carbon pools. Journal of Ecology 104:1020-1031. https://doi.org/10.1111/ $1365-2745.12571$

Zhu M, Hoctor T, Volk M et al (2015) The conservation value of elevation data accuracy and model sophistication in reserve design under sealevel rise. Ecology and Evolution 5:4376-4388. https://doi.org/10. 1002/ece3.1669 